\title{
Deception and earnings management: A textual analysis perspective
}

\author{
Lucas M. Dille PhD, CPA \\ Assistant Professor of Accounting \\ Robert W. Plaster College of Business \\ Missouri Southern State University \\ Dille-1@mssu.edu
}

\begin{abstract}
The definition of earnings management contains two elements: a departure from normal business practices and the use of deception to mislead stakeholders. Accounting literature has examined the two parts of the definition in isolation, allowing the qualitative and quantitative literature to reach different conclusions about earnings management. In this study I operationalize managerial intent, using textual analysis, to test the association between managerial deception and earnings management. I find evidence supporting the use of deceptive earnings management behavior by firms which are outside of the meet-or-beat earnings threshold, and very limited evidence supporting the use of deception within the meet-or-beat threshold. I further find a negative relationship between deception and abnormal production costs, suggesting deceptive executives have decreased production compared to non-deceptive executives.
\end{abstract}

Keywords: earnings management, textual analysis, content analysis, real earnings management, accruals earnings management

This paper is based on my dissertation at Morgan State University. I am grateful for the guidance I received from my dissertation committee chair, Shelia Thiruvadi, and the remainder of my committee, Kelly Carter, Phyllis Keys, and Abirami Radhakrishnan. I acknowledge ongoing support for this research from the Youngman Faculty Development Summer Scholar Fellowship Program through the Plaster College of Business as Missouri Southern State University. I thank the participants of workshops at Morgan State University, and Missouri Southern State University. 
Healy and Wahlen (1999) define earnings management as: "managers use judgment in financial reporting to either mislead some stakeholders about the underlying economic performance of the company or to influence contractual outcomes." This definition is composed of two distinct parts; the first is the judgment in financial reporting and the second is the intent of the manager to mislead stakeholders. Starting with Healy (1985) literature has explored how and why firms engage in earnings management (Bonacchi, Cipollini, \& Zarowin, 2018; Liu, Subramanyam, Zhang, \& Shi, 2018; Scott Asay, 2018), the effect of earnings management (Bereskin, Hsu, \& Rotenberg, 2018; Commerford, Hatfield, \& Houston, 2018; Khurana, Pereira, \& Zhang, 2018), and the relationship between auditors and earnings management (Choi, Choi, \& Sohn, 2018; Commerford, Hermanson, Houston, \& Peters, 2019).

Despite years of research literature has yet to empirically link managerial judgement with managerial intent. The quantitative literature has found instances where earnings management may be likely and has tested managerial judgement absent from managerial intent, and has found large degrees of earnings management throughout industries (Ball, 2013). The qualitative literature has examined managerial intent without examining judgement and has found that not all earnings management attempts are deceptive or misleading by intent.

I begin to build the missing link between managerial judgement and managerial intent using textual analysis. The linguistic and psychological literature has used textual analysis to understand the underlying message within a document for several decades. Recently, the accounting literature has used textual analysis to understand the intent of managers and glean more information from financial disclosures (Li, 2008, 2010; Loughran \& McDonald, 2011, 2016).

Earnings calls with analysts are nearly concurrent with the release of the annual report and it is one of the first times managers are formally questioned about the operating results. Although managers also reveal their true feelings and intentions during these calls. For example, on May 2, 2018, during an earnings conference call, Tesla CEO Elon Musk called one of the analysts "boring" and said they were asking "bonehead questions." These extempore comments were correlated with the Tesla stock pricing falling nearly five percent (Melloy, 2018). Although most executives are not as blunt as Mr. Musk, there are many instances where words can betray intentions. Therefore, I use textual analysis on the earnings calls to examine the intentions of the top executives on the earnings calls.

I follow Larcker and Zakolyukina (2012) and Hope and Wang (2018) and examine the underlying deception related to earnings management. Findings reveal that CEOs utilize real activities management (RAM, hereinafter) techniques whereas CFOs utilize discretionary accruals to accomplish their deceptive earnings management objectives. RAM can be expressed in three different ways: sales manipulation, over production, and reduction of discretionary expenses. I use the meet-or-beat earnings benchmark to differentiate between firms with (target firms) or without (non-target firms) a deceptive motive. Contrary to expectations, I detect no deception in target firms, and deception primarily in non-target firms. This suggests that the current findings and theories surrounding earnings management in the literature may not correctly differentiate between firms that are or are not deceptive. In addition, I find a negative relationship between executive deception and abnormal production costs, suggesting that executives engage in deception as production in their firms decreases. I find limited evidence associating the complexity of the annual report management discussion and analysis to the use of deception. 
This study contributes to the literature in several ways. First, I fill a gap as no other study has utilized textual analysis to operationalize managerial intent. The literature has utilized the theoretical definition of earnings management for thirty years without operationalizing the intent aspect of the definition. Researchers will now be able to assess the validity of the traditional earnings management measures against the intent of managers. Third, I investigate the relationship between CEOs and CFOs and their different preferences towards earnings management strategies. Finally, I reveal evidence suggesting deceptive executives have lower levels of production than their non-deceptive counterparts.

The differentiation between deceptive and traditional earnings management can aid researchers in focusing earnings management literature to better understand the characteristics of firms that engage in deceptive earnings management. In addition, the differentiation can aid regulators in deciding how to address deceptive earnings management behavior and develop regulatory measures to constrain deceptive firms without inhibiting non-deceptive firms.

The organization of the paper is as follows. I analyze the background literature surrounding earnings management and textual analysis literature. Following the literary foundation, I develop the hypotheses. I then discuss the data and methodology and evaluate the results. The final section discusses the conclusions, limitations, and directions for future research.

\section{LITERATURE REVIEW AND HYPTOHESIS DEVELOPMENT}

Schipper (1989) defines earnings management as “ . . . a purposeful intervention in the external financial reporting process, with the intent of obtaining some private ${ }^{1}$ gain (as opposed, to say, merely facilitating the neutral operation of the process)." The Schipper (1989) and Healy and Wahlen (1999) definitions of earnings management both include two conditions: managerial judgment and managerial intentions. The two definitions allow for a range of judgement, Healy (1999) includes deceit about underlying economics, and Schipper (1989) closes the range at some private gain. The quantitative literature has examined two tools to manipulate earnings: accruals earnings management (Dechow, 1994; Dechow, Sloan, \& Sweeny, 1995; Jones, 1991; S. Kothari, Leone, \& Wasley, 2005) and real activities management (Roychowdhury, 2006). Accruals earnings management operates under the premise that accruals are discretionary, and managers use their discretion to meet certain earnings targets.

Jones (1991) developed the foundation of the model used to identify traditional accruals earnings management by isolating the discretionary component of total accruals. The modified Jones model was developed by Dechow, Sloan, and Sweeny (1995) and incorporated the change of receivables into the model, as it is easier for managers to exercise judgment of credit, sales. The accruals management studies often find similar findings, but differ over the theoretical justifications. For example Teoh, Welch, and Wong (1998) look at current discretionary accruals and find firms with higher discretionary accruals have poorer financial performance in the years following an initial public offering (IPO). Teoh et al. (1998) motivate the study by observing the large degree of information asymmetry between mangers and potential investors at the time of the IPO, and assume that managers will engage in accruals manipulation to further capitalize on this information asymmetry.

\footnotetext{
${ }^{1}$ Schipper (1989) utilizes the word "private" to indicate any party in the agency relationship, including but not limited to the firm itself. For example, a manager (with no stock options) engaging in earnings management to meet the analyst's forecast to prevent a decline in stock value for the company would still be considered a "private gain."
} 
Shivakumar (2000), takes an opposite stance of Teoh et al. (1998), assumes that investors assume all firms will manipulate earnings upward, automatically deflating the firms' earnings. While agreeing that the mangers used discretionary judgements Teoh et al. (1998) and Shivakumar (2000) depart due to disputes about managerial intentions. Teoh et al. (1998) assumes managers are opportunistic and deceitful, whereas Shivakumar (2000) assumes managers are non-opportunistic and are attempting to neutrally facilitate the process ${ }^{2}$.

Klein (2002) finds evidence supporting a link between the CEO on the compensation committee and accruals earnings management. Klein (2002) offers two explanations for the result. In one, a board that allows a CEO to sit on the compensation committee is friendlier to the CEO and granting extra compensation. In contrast, the CEO could be maximizing their compensation by manipulating accruals when given the opportunity to sit on the compensation committee. The choice between these two plausible theories boils down to managerial intent.

The second common measure of earnings management, RAM, is defined as "departures from normal operational practices, motivated by manager's desire to mislead at least some stakeholders into believing certain financial reporting goals have been met in the normal course of operations" (Roychowdhury, 2006). These departures from normal business practices are typically found in temporary increases in sales, over production, and reduction of discretionary expenses. Although deceit ${ }^{3}$ is mentioned in the RAM definition, it is not operationalized within the models therefore intentional managerial deception is assumed by all studies using this model.

RAM has been most used by firms recently due to the difficulty in differentiating between normal and abnormal business judgements. The literature relies on the Roychowdhury (2006) models to create these distinctions, yet these distinctions were not tested alongside managerial intentions. Auditors have greater access to mangers to guess at intentions, but they often find RAM difficult to detect, and base their assessment of what RAM is on their litigation and business risk (Commerford et al., 2019; Kim \& Park, 2014).

The engagement in RAM has been associated with many different characteristics within firms. For example, Gunny (2010) provides evidence suggesting a decrease in future firm performance after engagement in RAM. Literature has also documented a reduction in performance following the use of RAM around equity offerings (Cohen, Dey, \& Lys, 2008; Cohen \& Zarowin, 2010; S. P. Kothari, Mizik, \& Roychowdhury, 2016; Mizik \& Jacobson, 2008). Kothari et al. (2016) find younger, less experienced firms have the poorest financial performance after a reduction in discretionary expenses. Leggett, Parsons, and Reitenga (2016) find an association between RAM and a negative effect on the return on assets and cashflow from operations. Recently, evidence has been provided that consolidated firms use the subsidiaries to engage in big picture RAM, as many investors may ignore the subsidiaries financial statements reviewing only the consolidated statements (Bonacchi et al., 2018).

Jarvinen and Myllyma (2016) find that firms with material internal control weaknesses are more likely to engage in RAM, and have a greater degree of earnings management behavior, particularly in over production and discretionary expenses, in the year following the material weakness disclosure. Jarvinen and Myllyma (2016) suggest the increase in RAM is to soften the

\footnotetext{
${ }^{2}$ It is assumed that managers rationally believe that investors expect firms to overvalue earnings, therefore the manager does manipulate earnings, but not with a deceitful intent, as the market is expecting and adjusting for deceit.

${ }^{3}$ When looking at the definition of mislead and deceit, mislead is defined as "to lead in a wrong direction or into a mistaken action or belief often by deliberate deceit" (Merriam-Webster.com, 2020). As misleading utilizes deceit within the definition I use these words interchangeably.
} 
market reaction from the disclosure of the material weakness. Alternatively, the RAM may also be explained by the effect material internal control weaknesses have on operations (Feng, Li, McVay, \& Ashbaugh-Skaife, 2015).

Kim and Park (2014) find that auditors are less likely to retain clients that engage in RAM to avoid the litigation risk associated with RAM practices. In a city level setting, it has been found that engagement in RAM is associated with an increased auditor tenure, and with higher quality audits (Chi, Lisic, \& Pevzner, 2011). After numerous interviews with auditors, RAM was found to threaten the comfort of the auditors due to management's focus on the shortterm, opposed to the long-term, prospects of a company (Commerford, Hermanson, Houston, \& Peters, 2016). The engagement in RAM gives the auditor a negative perception of management and may cause the auditor to make unnecessary audit adjustments due to the heightened scrutiny (Commerford et al., 2018, 2019).

Although definitionally implied, accruals earnings management and RAM do not test for the intent of managers. Instead, the front-runners of these techniques focused on small subsets of populations where there was a large amount of theoretical evidence to suggest some form of earnings management behavior. Some of these areas include the convergence of firms around the meet-or-beat benchmark (Bartov \& Cohen, 2008; Burgstahler \& Dichev, 1997). Shortly thereafter studies looked for any area where there is incentive to manage earnings (Becker, Defond, Jiambalvo, \& Subramanyam, 1998; Cohen et al., 2008; Gunny, 2005), drawing conclusions about managerial behavior without testing intent.

The study and identification of earnings management behavior is full of nuances and complexities, including but not limited to the difficulty of operationalizing intent (Dechow \& Skinner, 2000; Schipper, 1989). Parfet (2000) ranks acceptable and unacceptable forms of earnings management techniques. When literature focuses on judgement or intent in isolation it begins to appear that earnings management behavior is rife within the practice (Ball, 2013). Ball (2013) notes the lack of practical evidence supporting academia's claim, including the lack of prosecutions, and the lack of action by parities better incentivized to prevent these attempts, such as internal and external auditors, whistleblowers, short sellers, and boards. Many stakeholders would have to look the other way for the degree of earnings management suggested by literature to be the reality.

Literature has also looked at managerial intentions in isolation from managerial judgements. Bruns and Merchant (1990) asked managers whether the executive believes the decision to engage in earnings management is ethical. Bruns and Merchant (1990) find that 57\% of surveyed managers believe it is ethical to alter operating decisions to increase earnings and $79 \%$ believe it is ethical to make decisions to reduce earnings. Bruns and Merchant (1990) even conclude that managers may not realize that their behavior is immoral, which draws into question whether there is a deceptive intent.

Nelson et al. (2002) surveyed auditors and found in $28 \%$ of cases when earnings management is involved, and the incentive is to meet analysts' expectations, that auditors recommend adjustments. The auditors made more adjustments when the earnings management attempt was material. Every other incentive that affected the stock markets such as the stock price, new IPOs, and company sales were adjusted by auditors over $50 \%$ of the time.

Auditors have a responsibility that earnings are reported fairly which means that when auditors do not suggest adjustments in cases of earnings management, the auditors believe it is a fair economic representation of the firm. As Nelson et al (2002) found, auditors recommend adjustments less than a third of the time when the firm's objective is to meet analysts' 
expectations. Although Nelson et al. (2002) do not specify firm characteristics of adjustments specifically regarding meeting analysts' expectations, in general they find larger firms are adjusted less often.

Kaplan (2001) finds that an individual's perspective in the reporting process largely determines the acceptability of a particular earnings management practice. Further, Kaplan (2001) concludes that societal agreement on the acceptability of earnings management practices may be impossible to achieve. The qualitative data paint a much more detailed narrative than the quantitative literature leads one to believe.

The quantitative and qualitative literature end up at crossroads, where one points to earnings management being pervasive and deceitful, and the other shows the nuanced effect motivation and perspective have on earnings management. Textual analysis is a growing technique in accounting research that can close the gap in these narratives by reconciling the motivations of managers with the financial variables. Li (2008) looked at the characteristics, rather than the financial content, of disclosure on a large scale. Li (2008) examined the readability of the annual report and found that longer and harder to read annual reports tend to have less persistent positive earnings, providing evidence that managers attempt to conceal information within the financial data as well as the written disclosures.

Lo, Ramos, and Rogo (2017) build upon Li (2008) and isolate their analysis to the MD\&A section of the annual report as executives are allowed more freedom to express their positions in the MD\&A providing a truer representation of their intentions. Overall, Lo et al (2017) support the results of $\mathrm{Li}$ (2008) and find that readability, proxied by the Gunning fog index ${ }^{4}$ (FOG index, hereinafter), significantly decreases around the meet-or-beat earnings benchmark. This supports the idea that some managers attempt to obscure information and disclosures of their firm by making their annual reports overly complicated.

Literature has moved beyond readability measure and moved to examine the underlying tone of a document. The bag-of-words approach uses a list of words or phrases and counts how many times words from the targeted list appear in the document (Loughran \& McDonald, 2016). Utilizing word lists has had success in other fields, although financial texts provide an extra challenge to conventional word lists, since words take on different connotations within the field. It has been found that nearly three-quarters of words that are considered negative in a traditional context do not actually have a negative connotation in the financial context (Loughran \& McDonald, 2011).

With this limitation in mind, Loughran and McDonald (2011) developed a word list specifically for use in financial contexts of 10-K annual reports. In this quest, the authors created five additional lists and found a relationship between market reaction and the frequency of certain words on their word count. Their article provides evidence of potentially two ideas: either that the tone of a report is a proxy for the actual financial data, or that investors can discern the tone and react accordingly.

Carlsson and Lamti (2015) utilize a modified version of the Loughran and McDonald (2011) word list to evaluate earnings management and tone. Evidence is provided that managers with a positive tone are more likely to engage in accruals earnings management (Carlsson \& Lamti, 2015). Purda and Skillicorn (2015) take a different approach to the word lists and train a computer program to recognize words indicative of fraud utilizing the Management Discussion and Analysis from the annual and interim $10-\mathrm{K}$ and $10-\mathrm{Q}$ reports and find that language can be an effective indicator of fraud.

\footnotetext{
${ }^{4} \mathrm{FOG}=0.4 *$ (words per sentence + percent of complex words $)$ where complex words are 3 or more syllables
} 
Many textual analysis studies within the accounting literature have utilized the annual reports as a data source, but another source is the annual conference calls discussing the prior year performance and directions for the future once the annual report has been released. Larcker and Zakolyukina (2012) utilize the annual conference calls and further refine a word list for the accounting context and create a deception model to identify truthful and deceptive speech from the CEO and CFO. The word lists are based upon the linguistic, psychological, and deception detection literatures which have been able to differentiate between truthful and false narratives using the spoken or written word (Larcker \& Zakolyukina, 2012). The authors use the assumption that the CEO and CFO know whether the financial statements are manipulated and that the manager's speech in spontaneous encounters, such as conference calls, betrays their underlying motives.

Larcker and Zakolyukina (2012) utilize four different prediction models to examine instances of possible deception and to identify which words, associated with deception in a general context, are used to deceive stakeholders in the financial context. Three prediction models are based on causes of restatements, and the fourth model is based upon formal SEC investigations which lead to an Accounting and Auditing Enforcement Release (AAER). The models are then used to predict accounting manipulations in out-of-sample tests. When tested against traditional financial models for manipulation identification, all four word list models outperform their financial counterparts (Larcker \& Zakolyukina, 2012).

Hope and Wang (2018) utilize the Larcker and Zakolyukina (2012) deception index to look at the information asymmetry effects of deceptive CEOs following a big bath. The authors find that information asymmetry increases when the CEO is more deceptive. Their findings provide evidence that investors can discern whether a CEO is being truthful and react accordingly. Deceptive executives tend to use more general knowledge and have fewer references to shareholder value (Larcker \& Zakolyukina, 2012). Larcker and Zakolyukina (2012) further find that the deceptive CEOs use extremely positive language, whereas deceptive CFOs use a greater number of negative emotive words.

With the recent introduction of textual analysis to the accounting literature, there has been little development beyond validating word lists for use in the financial context. I begin to fill this gap by utilizing a validated word list for detecting deception in the financial context, to empirically explore the relationship between quantitative measures and manager's deceptive intent.

To determine managerial intent, I use transcripts from the end-of-the-year conference calls. Managers are less likely to guard their tone during earnings calls with analysts, as it is less formal than an SEC disclosure and the question-and-answer period provides an opportunity for impromptu responses (Larcker \& Zakolyukina, 2012; Loughran \& McDonald, 2016).

A timeline shown in figure 1 illustrates where a conference call falls during the year, in relation to the rest of the reporting period. The timeline is split into two halves: the reporting period and the audit period. During the reporting period, the manager utilizes his or her judgment to run operations and make accounting decisions; engagement in traditional or deceptive earnings management is done during this period.

\section{[INSERT FIGURE 1 ABOUT HERE]}

During the audit period, the firm may or may not conduct a guidance call, which attempts to decrease the information asymmetry between the managers and the analysts, so expectations are closer to reality. The firm can then choose to release its earnings prior to the release of the audited annual report, or it can wait until the release of the annual report. During the audit 
period, the auditor can recommend adjustments to reduce or eliminate any accruals earnings management techniques attempted by management. If any RAM decisions had been made during the period, they cannot be adjusted by auditors as they are an operating decision, not a direct accounting manipulation.

The audited annual report is released after the completion of the audit and shortly thereafter the conference call is conducted to discuss the performance of the company. The conference call is held after the release of the financial reports to allow the analysts to review the report and ask informed questions regarding the company's past performance. The timing is important as this is the first-time management must publicly defend the operating decisions of the prior fiscal year, in a less formal setting than the annual report. It is therefore expected that, given the less formal and impromptu nature of the conference call, the underlying intent of the managers will be revealed.

To evaluate the deception used by target firms I first evaluate the entire sample population for the use of deception. The hypotheses then split to look at the use of deception in target and non-target firms. I identify target firms as firms that meet-or-beat earnings as there is an unusual grouping of firms at this benchmark, there are many incentives to avoid reporting a loss, and traditional earnings management measures were developed around this benchmark (Burgstahler \& Dichev, 1997; Roychowdhury, 2006). Many earnings management studies and measurements have been developed around this benchmark, therefore I expect this benchmark to be the most likely place to find a deceptive intent and therefore have an association between deception and the earnings management measure. I expect non-target firms will have no association between deception and the earnings management measure.

Hypotheses 1 and 2 examine the CEO's and CFO's speech during the conference call. In addition, a different group of firms is examined in each subset of the hypotheses. The first set of hypotheses examines accruals management, using the modified Jones approach (Dechow et al., 1995), as the measure of traditional earnings management. A positive association between discretionary accruals and CEO and CFO deception is hypothesized when looking at all firms because it is expected that the target firms will be driving the result as they are predicted to be the only ones engaging in deceptive earnings management. A lack of association between deception and non-target firms' discretionary accruals will provide evidence of differentiation between deceptive and traditional earnings management.

The formal hypotheses follow.

Hypothesis la:

When examining all firms, there will be a positive association between CEO deception and discretionary accruals.

Hypothesis $1 b$ :

When examining the target firms, there will be a positive association between CEO deception and discretionary accruals.

Hypothesis 1c:

When excluding target firms, there will be no association between CEO deception and discretionary accruals.

Hypothesis $2 a$ :

When examining all firms, there will be a positive association between CFO deception and discretionary accruals.

Hypothesis $2 b$ : 
When examining the target firms, there will be a positive association between CFO deception and discretionary accruals.

Hypothesis 2c:

When excluding target firms, there will be no association between CFO deception and discretionary accruals.

The second set of hypotheses mirror the first two hypotheses, but this time they measure RAM. RAM will be measured following Roychowdhury (2006).

Hypothesis $3 a$ :

When examining all firms, there will be a positive association between CEO deception and the use of real activities management.

Hypothesis $3 b$ :

When examining target firms, there will be a positive association between CEO deception and the use of real activities management.

Hypothesis 3c:

When excluding target firms, there will be no association between CEO deception and the use of real activities management.

Hypothesis 4a:

When examining all firms, there will be a positive association between CFO deception and the use of real activities management.

Hypothesis $4 b$ :

When examining target firms, there will be a positive association between CFO deception and the use of real activities management.

Hypothesis $4 c$ :

When excluding target firms, there will be no association between CFO deception and the use of real activities management.

\section{Model Development}

\section{DATA AND METHODOLOGY}

I utilize the modified Jones model to estimate the discretionary accruals (Dechow et al., 1995; Jones, 1991). I follow prior research (Cohen et al., 2008) and estimate the model for each two-digit SIC industry as follows:

Model 1:

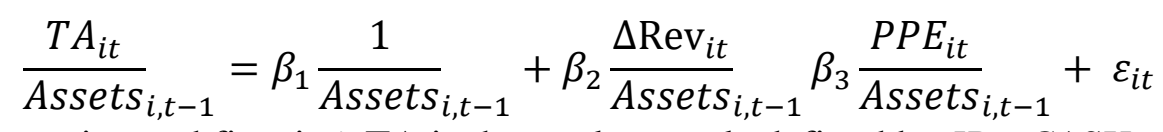

Where fiscal year is $t$ and firm is $i$, TA is the total accruals defined by $I B_{i t}-C A S H_{i t}$ where $I B$ is the earnings before extraordinary items and discontinued operations and $C A S H$ is the operating cash flows. Assets are the total assets and $\triangle R e v$ is change in revenue from the prior year. $P P E^{5}$ is the property, plant, and equipment.

The coefficients from the first model are then used to estimate the normal accruals $(N A)$ for each sample firm:

Model 2:

$$
N A_{i t}=\hat{\beta}_{1} \frac{1}{\operatorname{Assets}_{i, t-1}}+\hat{\beta}_{2} \frac{\left(\Delta R E V_{i t}-\Delta A R_{i t}\right)}{A S S E T S_{i, t-1}}+\hat{\beta}_{3} \frac{P P E_{i t}}{\operatorname{Assets}_{i, t-1}}
$$

Where $\triangle A R$ is the change in accounts receivables from the prior year. The industry-specific regressions assume there are no discretionary revenue recognition choices. Following the

\footnotetext{
${ }^{5}$ Unless otherwise stated, all independent variables are measured at book value.
} 
literature, the reported revenues are adjusted by accounts receivables to account for discretion surrounding credit sales. Discretionary accruals are calculated as:

Model 3:

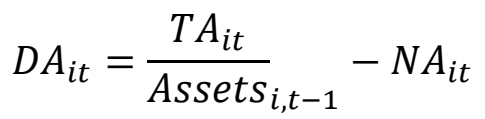

I utilize the discretionary accruals in the following model to examine the association between deception and accruals.

Model 4:

$$
\begin{gathered}
\text { DECP }_{t}=\alpha_{1}+\beta_{1} D_{i t}+\beta_{2} L_{E V}+\beta_{i t} \text { ROA }_{i t}+\beta_{4} \text { ASSETGROWTH }_{i t}+\beta_{5} \text { InASSETS }_{i t} \\
+\beta_{6} \text { RESTATE } \\
+\beta_{7} \text { LOSS }_{i t}+\varepsilon_{t}
\end{gathered}
$$

Where $D A$ is the discretionary accruals as calculated in model 3. $L E V$ is the total debt over ASSETS for year t; as a firm's leverage increases, there is an association with violating possible debt covenants (Press \& Weintrop, 1990). The executives may try to present a more optimistic picture of the firm to prevent any negative changes or violating debt covenants. Therefore, I expect a positive relationship between $L E V$ and $D E C P$.

$R O A$ is the Net Income (NI) divided by ASSETS for year t; ROA is utilized to control for the performance of the company (Zang, 2012). ASSETGROWTH is calculated by $\left(A S S E T S_{t^{-}}\right.$ $\left.\operatorname{ASSETS~}_{t-1}\right) /\left(\right.$ ASSETS $\left._{t-1}\right)$; this controls for the growth of the firm. InASSETS is the natural $\log$ of ASSETS for period $\mathrm{t}$ and is a proxy for the size of the company (Klein, 2002). RESTATE is a dummy variable that is coded 1 if the earnings have been restated due to fraud and 0 otherwise. Larcker and Zakolyukina (2012) found the word associations by using restatements and AAERs. I control for restatements as an executive may be deceptive to conceal the restatements. LOSS is a dummy variable coded as 1 if the firm reported a loss for the period; executives may also be deceptive trying to conceal or understate the reasons for the loss in the earnings call (Klein, 2002; Lo et al., 2017).

Model 4 is used to test the first two hypotheses. The next set of models is used to test hypotheses three and four. Model 5 follows Dechow et al. (1998) and Roychowdhury (2006) and expresses normal cash flows as a linear function of sales and the change of sales, by industry and year.

Model 5:

$$
\frac{\text { CASH }_{t}}{\operatorname{ASSETS~}_{t-1}}=\alpha_{0}+\alpha_{1} \frac{1}{\operatorname{ASSETS~}_{t-1}}+\beta_{1} \frac{\operatorname{SALES}_{t}}{\operatorname{ASSETS~}_{t-1}}+\beta_{2} \frac{\Delta S A L E S_{t}}{\operatorname{ASSETS~}_{t-1}}+\varepsilon_{t}
$$

Where $C A S H$ is the cash flows from operations. SALES are the reported sales for period $t$ and $\triangle S A L E S_{t}$ is the difference sale between the current period and the prior period. I estimate the normal cash flows by utilizing the coefficients from model 5. I subtract the normal cash flows from the actual cash flows to find the abnormal cash flows.

I estimate the normal cost of goods sold, COGS, following Dechow et al. (1998) and Roychowdhury (2006) as:

Model 6:

$$
\frac{\operatorname{COGS}_{t}}{\operatorname{ASSETS}_{t-1}}=\alpha_{0}+\alpha_{1} \frac{1}{\operatorname{ASSETS}_{t-1}}+\beta_{1} \frac{\operatorname{SALES}_{t}}{A S S E T S_{t-1}}+\varepsilon_{t}
$$

Following Dechow et al. (1998) and Roychowdhury (2006), I estimate the model for normal inventory growth as follows.

Model 7:

$$
\frac{\Delta I N V_{t}}{\operatorname{ASSETS~}_{t-1}}=\alpha_{0}+\alpha_{1} \frac{1}{\operatorname{ASSETS~}_{t-1}}+\beta_{1} \frac{\Delta S A L E S_{t}}{\operatorname{ASSETS~}_{t-1}}+\beta_{2} \frac{\Delta S A L E S_{t-1}}{\operatorname{ASSETS~}_{t-1}}+\varepsilon_{t}
$$


Where $\triangle I N V$ is the change in inventory in period t.

I use the definition of production costs, PROD, from Roychowdhury (2006) where PROD $=\mathrm{COGS}_{\mathrm{t}}+\Delta I N V_{\mathrm{t}}$. Using models 6 and 7 normal production costs are estimated as follows.

Model 8:

$$
\frac{\text { PROD }_{t}}{\text { ASSET }_{t-1}}=\alpha_{0}+\alpha_{1} \frac{1}{\text { ASSETS }_{t-1}}+\beta_{1} \frac{\text { SALES }_{t}}{\text { ASSET }_{t-1}}+\beta_{2} \frac{\Delta S A L E S_{t}}{\text { ASSETS }_{t-1}}+\beta_{3} \frac{\Delta S A L E S_{t-1}}{\text { ASSET }_{t-1}}+\varepsilon_{t}
$$

Roychowdhury (2006) differs from Dechow et al. (1998) and estimates discretionary

expenses, DISEXP, utilizing lagged sales in lieu of current sales, to avoid the uncharacteristically low residuals created by the regression with current sales.

Model 9:

$$
\frac{\operatorname{DISEXP}_{t}}{\operatorname{ASSETS}_{t-1}}=\alpha_{0}+\alpha_{1} \frac{1}{\operatorname{ASSETS}_{t-1}}+\beta_{1} \frac{\operatorname{SALES}_{t-1}}{\operatorname{ASSETS}_{t-1}}+\varepsilon_{t}
$$

Having defined the RAM variables, I utilize them to test hypotheses 3 and 4 in the following model.

Model 10:

$$
\begin{gathered}
\text { DECP }_{t}=\alpha_{1}+\beta_{1} \text { RAM }_{i t}+\beta_{2} \text { LEV }_{i t}+\beta_{3} \text { ROA }_{i t}+\beta_{4} \text { ASSETGROWT }_{i t}+\beta_{5} \text { InASSETS }_{i t} \\
+\beta_{6} \text { RESTATE }_{i}+\beta_{7} \text { LOSS }_{i t}+\varepsilon_{t}
\end{gathered}
$$

Where $R A M$ is defined as the individual measures, abnormal cash flows ( $\left.A B N \_C F O\right)$, abnormal production costs $\left(A B N \_P R O D\right)$, and abnormal discretionary expenses $\left(A B N \_D I S E X P\right)$. The control variables used are the same as those in Model 4 and found in prior RAM research, (Cohen \& Zarowin, 2010; Gunny, 2005; Larcker \& Zakolyukina, 2012).

When examining the use of annual reports for hypothesis 5, I use Python to parse out the management discussion and analysis (Item 7 of the 10-k) and to calculate the readability statistics. The annual reports are then combined with the necessary data from Compustat, CRSP and Audit Analytics.

\section{Data Collection and Descriptive Statistics}

I utilize Python to collect the earnings call transcripts from http://seekingalpha.com/earnings/earnings-call-transcripts. Seeking Alpha has been used as a source of earnings call transcripts by Allee and Deangelis (2015) and Hope and Wang (2018). The time period of the sample is 2010-2016. SeekingAlpha.com started the transcript curating process in 2006 and there is a limited sample of usable transcripts prior to 2010.

The initial sample started with over 100,000 fourth-quarter earnings call transcripts. I combined the transcripts with Compustat and Audit Analytics. Consistent with current practice, I removed all firms in the financial and utility industries and those without the necessary financial data available. Firms included needed a word count of 100 words or greater by the respective executive (Hope \& Wang, 2018). Each industry year was required to have at least eight observations by two-digit SIC code (Cohen et al., 2008). Due to the nature of the analysis, I had two samples: the CEO sample and the CFO sample. The final CEO sample was composed of 8,581 firm-year observations from 2,716 firms. The final CFO sample was composed of 8,442 firm-year observations from 2,732 firms. The industry composition of the sample can be seen in Table 1. No agriculture firms are present in the sample as they were removed due to the eight-firm per industry year requirement. A little over half of the sample is composed of manufacturing firms and approximately $20 \%$ is made up of the service industry.

[INSERT TABLE 1 ABOUT HERE]

The conference call transcripts are composed of four different parts: the header, operator introduction, executive prepared remarks, and the question and answer period. The header 
contains the company name, ticker, the listing stock exchange, the quarter of the call, the date and a list of the call's participants including executives and analysts. The operator introduction states the company year, the quarter, and introduces the first speaker. The third portion of the transcript is the prepared statements from the CEO, CFO, and various other executives. The fourth portion of the transcript consists of analysts' questions and the executive answers. While the opening statements are generally scripted, Larcker and Zakolyukina (2012) find similar results when looking at the prepared remarks and the question and answer period, which is impromptu. In my analysis, I combine the prepared executive statements and the question and answer period.

I utilize Python to parse out the company name, ticker, quarter and fiscal year of the call, CEO and CFO names, and the names of the remaining executives and analysts. I then programmatically separate the CEO and the CFO speech into text files, one for the CEO and one for the CFO. Following Larcker and Zakolyukina (2012) and Hope and Wang (2018), I utilize the Linguistic Inquiry and Word Count (LIWC) psychosocial dictionary (Pennebaker, Boyd, Jordan, \& Blackburn, 2015) for the textual analysis.

The LIWC software counts the number of times a word appears in the transcript. In addition to the internal dictionary, I added in a custom dictionary developed by Larcker and Zakolyukina (2012). They find that deceptive CEOs are positively associated with the use of extremely positive emotion words and references to general knowledge. CEO deception is negatively associated with anxiety words and shareholder value. Larcker and Zakolyukina (2012) further find that CFO deception is positively associated with word count, negations, extremely negative emotions and negatively associated with first-person pronouns and impersonal pronouns.

Similar to Hope and Wang (2018), I operationalize Larcker and Zakolyukina (2012) findings by creating a deception score. For each category of word, I find the median word use and then assign a value of 2 (1) to the firm for that category if the firm has a greater (below or equal) to median value. If the category is negatively associated with deception, then I assign a value of 1 (2) to the firm for that category if the firm has a greater (below or equal) to median value. I aggregate the score from all categories and standardize the results, creating a deception Z-score (DECP). The DECP variable is coded as CEO_DECP and CFO_DECP for the respective executive's speech sample. I also created an additional measure of DECP_X. This measure includes only the deceptive word categories for the respective executives. The reason for this is that there is no theoretical backing associating these categories with truthfulness, and there could be other explanations for the negative association found by Larcker and Zakolyukina (2012). A list of variables and their respective definitions can be found in Appendix B.

\section{Descriptive Statistics}

The descriptive statistics for both the CEO and CFO are in the Table 2. All continuous variables, other than word count, were winsorized at the 1 percent and 99 percent levels. The standardized deception score is noted along with the individual word categories that make up the score. The mean word use in each category reference to general knowledge (REFGK), extreme positive emotions (XPOSEMOT), anxiety (ANX), negations (NEGATE), swear words (SWEAR), extreme negative emotions (XNEGEMOT), first-person pronouns (I), impersonal pronouns (THEY), and shareholder value (SV) words are in line with prior research (Hope \& Wang, 2018; Larcker \& Zakolyukina, 2012). The words associated with each category are listed in Appendix A. The mean word use of CEOs is approximately 800 words greater than that of the CFOs. This is generally because the CEO has a much larger purview than the CFO and may talk 
more about the overall direction of the company, in addition to the financial outcomes and goals of the firm, whereas the CFO typically discusses only the financial outcome and goals of a firm.

[INSERT TABLE 2 ABOUT HERE]

There is a large standard deviation for the word count of both samples. This is similar to prior research. The mean return on assets (ROA) is -0.0175 and -0.0116 for the CEO and CFO samples respectively. In addition, in both samples, the firms have leverage of 0.5176 and 0.5188 for the CEO and CFO samples. This high leverage ratio could be a result of the large proportion of manufacturing firms within the sample.

The correlation tables for the CEO and CFO sample are listed in the Table 3 Panel A and Panel B respectively. CFO_DECP and CFO_DECP_X are correlated with most independent variables although the VIF in all cases is less than 10, and generally less than 2.

\section{[INSERT TABLE 3 ABOUT HERE]}

\section{Hypothesis 1}

\section{RESULTS}

Hypothesis 1 examines the relationship between CEO deception and discretionary accruals utilizing model 4 . The results for hypothesis $1 \mathrm{a}, 1 \mathrm{~b}$, and $1 \mathrm{c}$ can be seen in table 4 . The model includes both year and industry fixed effects. There was no association found between CEO_DECP and discretionary accruals. A negative association was found between CEO_DECP and fraudulent restatements, contrary to the predicted positive relationship. A positive relationship was expected as the deception index was developed using restatements as a deception proxy (Larcker \& Zakolyukina, 2012), although the opposite relation may be caused because I used a less nuanced restatement measure than Larcker and Zakolyukina (2012).

\section{[INSERT TABLE 4 ABOUT HERE]}

Target firms are defined in two different ways. The first is if the earnings per share are within $\$ 0.03$ of the prior year. This measure was used in Lo, Ramos, and Rogo (2017), here forth referred to as the EPS measure. The second measure follows Roychowdhury's (2006) measure of suspect firms, where net income scaled by assets is greater than or equal to zero but less than 0.005 , here on referred to as the suspect firm measure. In both these categories, there was no association found. Given the results, the null hypothesis cannot be rejected and hypothesis 1 is not supported.

The lack of support for a relationship between CEO deception and accruals earnings management suggests that the modified Jones model does not capture managerial intent in the full sample, or at the meet or beat earnings benchmark. Accruals earnings management is not relied upon as much by managers in recent times (Cohen et al., 2008), so a sample which uses a different benchmark may still be able to find an empirical link between deception and the modified Jones model.

\section{Hypothesis 2}

Hypothesis 2 examines the relationship between CFO deception and discretionary accruals utilizing model 4 . The results for hypothesis $2 \mathrm{a}, 2 \mathrm{~b}$, and $2 \mathrm{c}$ can be seen in Table 5 . There is not a significant association between CFO_DECP and discretionary accruals. There is a significant positive association between CFO_DECP and lnAssets. When the deception index is modified to only include the deceptive categories of speech, a significant negative association ( $p$ $<.05)$ is found between CFO_DECP_X and discretionary accruals. This supports hypothesis $2 \mathrm{a}$. In addition, CFO_DECP_X is positively associated with leverage as predicted. There was also a positive association found with ROA, AssetGrowth, and lnAssets.

[INSERT TABLE 5 ABOUT HERE] 
Examining hypotheses $2 \mathrm{~b}$ and $2 \mathrm{c}$ yielded the following results. When target firms are defined using the EPS measure, there was a sample size of 292 target firms and 8150 non-target firms. There was no association found between CFO_DECP_X and discretionary accruals in the target firm sample, providing no support for hypothesis $2 \mathrm{~b}$. There was a negative association found between CFO_DECP_X and discretionary accruals when examining non-target firms. When using the suspect firm measure the sample size of the target firms was 146, and there were 8296 non-target firms. There were no significant associations found. This suggests that managers utilizing deceptive earnings management are not upwardly managing earnings, as thought in the development of the modified Jones model (Dechow et al., 1995). In addition, a lack of association found in target firms may suggest that when managers engage in earnings management to meet or beat a benchmark, it is done for non-deceptive reasons as suggested by Shivakumar (2000). Yet the association between CFO deception and the downward managing of accruals in non-target firms suggests deceptive earnings management is more prevalent than expected.

\section{Hypothesis 3}

The third set of hypotheses examine CEO deception and the RAM measures. The results can be found in Table 6.1. There was no association found between CEO_DECP or CEO_DECP_X and ABN_CFO. As expected, there were also no associations when the sample population was split between the target and non-target populations. This suggests that the ABN_CFO by itself does not capture a misleading CEO intent, as defined by (Roychowdhury, 2006), and may only be a measure of traditional earnings management.

[INSERT TABLE 6.1 ABOUT HERE]

The results of the CEO deception measure and abn_PROD can be seen on Table 6.2. There is a significantly negative association between both CEO deception measures and abn_PROD $(\mathrm{P}<0.001)$ when the full sample was examined. When limiting the sample to firms near the meet-or-beat benchmark, using either the EPS measure or the Roychowdhury's (2006), I find a significant negative association $(\mathrm{p}<0.05)$ between CEO_DECP and abn_PROD and I find a significant negative association $(\mathrm{p}<0.1)$ between CEO_DECP_X and abn_PROD. When examining the non-target firm sample, I find a significant negative association $(\mathrm{p}<0.000)$ between both CEO deception measures and abn_PROD.

[INSERT TABLE 6.2 ABOUT HERE]

Looking at the final RAM measure, abn_DISEXP, the results are presented in Table 6.3. There is a significant positive association $(\mathrm{p}<0.000)$ for both deception measures and abn_DISEXP. There is a significant positive association $(\mathrm{p}<0.000)$ between CEO_DECP and abn_DISEXP when the sample is limited to the target firms, using the EPS definition, and a significant positive association $(\mathrm{p}<0.05)$ between CEO_DECP and abn_DISEXP using the Roychowdhury's (2006) definition. Using the narrowed measure CEO_DECP_X, I find no association between the measure and abn_DISEXP when limiting the sample to target firms.

[INSERT TABLE 6.3 ABOUT HERE]

When examining the non-target firm sample, there is a significant positive association $(\mathrm{p}<0.000)$ between CEO_DECP and abn_DISEXP using both measures of the target firms. In addition, I find a positive association $(\mathrm{p}<0.000)$ between CEO_DECP_X and abn_DISEXP using both definitions of target firms.

The association between the deception measure and ABN_PROD and ABN_DISSEXP provides support for the Roychowdhury (2006) definition of RAM, by empirically linking deceptive managerial intent to abnormal operating decisions. This provides support that the 
production and discretionary expense measures are truly measuring deceptive earnings management, and not just traditional earnings management. The association between the deception measure and the use of RAM by non-target firms also provides validation to studies that use RAM outside of the meet or beat earnings threshold (Becker et al., 1998; Bonacchi et al., 2018; Cohen et al., 2008; Gunny, 2010; Khurana et al., 2018; Liu et al., 2018).

\section{Hypothesis 4}

Hypothesis 4a, 4b, and 4c all examined the relationship between CFO deception, the RAM measures, abnormal cash flows from operations, abnormal production costs and abnormal discretionary expenses. The results are presented in Table 7.1 (ABN_CFO), Table 7.2 (ABN_PROD), and Table 7.3 (ABN_DISEXP). There was no significant association found between CFO_DECP and the three respective RAM indicators. This may be the case as the measure includes both deceptive words and categories of non-deceptive words, in the financial context, which have not be externally validated (Larcker \& Zakolyukina, 2012).

[INSERT TABLES 7.1, 7.2, 7.3 ABOUT HERE]

When using the narrowed measure of CFO_DECP X there was a significant positive association $(\mathrm{p}<0.05)$ found between the deception measure and abn_CFO, and a significant negative association $(\mathrm{p}<0.05)$ found between the deception measure abn_Prod. There was no association found between the deception measure and abn_DISEXP. For all three RAM indicators, CFO_DECP_X was significantly positively associated with LEV and $\ln$ Assets, and negatively associated with AssetGrowth.

Shifting attention to hypothesis $4 \mathrm{~b}$ and $4 \mathrm{c}$, as expected there were no associations between the deception measures and Disexp. For abn_CFO, Table 7.1, there was no association between either deception measure and abn_CFO when looking at the target firms using the EPS measure. When using the suspect firm measure, there was a positive association $(\mathrm{p}<0.1)$ found between CFO_DECP_X and abn_CFO. When looking at the sample of non-target firms, there was a positive association found between CFO_DECP $(\mathrm{p}<0.1)$ and abn_CFO and CFO_DECP_X $(\mathrm{p}<0.05)$ and abn_CFO. Utilizing the suspect firm definition there was a positive association $(\mathrm{p}<0.05)$ between CFO_DECP_X and abn_CFO. This provides empirical support to the full RAM definition (Roychowdhury, 2006) and the theoretical definitions (Healy \& Wahlen, 1999; Schipper, 1989) providing evidence that RAM is carried out with a deceptive managerial intent. In addition, the associations found in the non-target firms demonstrates that RAM may be carried out with a deceptive intent when there is no clear incentive for managers to manage earnings.

There was no association found for CFO_DECP and abn_PROD when examining target and non-target firm measures. There is a negative association between CFO_DECP_X and abn_PROD $(\mathrm{p}<0.05)$ when looking at the target firms using the suspect firm measure. When evaluating the sample that excludes the target firms, there is a negative association between CFO_DECP_X and abn_Prod utilizing both the EPS measure and the suspect firm measure.

It might be expected that the results of the CEO and CFO deception should mirror each other. The evidence supporting CFO deception and earnings management were primarily found when examining discretionary accruals, whereas the evidence supporting CEO deception and earnings management was primarily found when evaluating the RAM measures. The discrepancy may lie in the overall strategy and roles of each position. The CEO sets the strategy of the company and is the leader when it comes to operational decisions, which may be why the evidence associating deception and earnings management was found in the operational earnings management techniques. The CFO supports the CEO's vision but also has a greater impact over 
the accounting estimates and judgments utilized. Therefore, a greater association was found in the discretionary accruals measures, but not the RAM measures.

\section{Robustness Tests}

There is a lapse of time between the manager's use of an earnings management technique and the fourth quarter earnings call. The delay raises the question of whether deception contributes to the use of earnings management or does the use of earnings management contribute to deception. The theoretical definition of earnings management suggests the latter is the case.

The Granger causality test allows us to test this relationship. While not proving causality, the Granger tests checks to see if the predictability of the autocorrelation of one variable is improved by adding in an additional variable. Essentially is there additional information in $\mathrm{Y}$ that can explain X. I test two null hypotheses in non-tabulated results; the first is that the deception measure $(\mathrm{X})$ is influenced by itself and not by the earnings management measure (Y). The second is that the earnings management $(\mathrm{X})$ measure is influenced by itself and not by the deception measure (Y). The test was run using five years of data (five lags) for both the deception measure and the earnings management measure.

There is no instance where the second null hypothesis, earnings management is influenced by itself and not the deception measure can be rejected. I found both CEO deception measures granger cause abn_PROD, therefore rejecting the first null hypothesis. When evaluating the CFO deception measures, I found that CFO_DECP granger causes DA.

The results indicate that the earnings management measures provide additional information to the deception measure. This provides evidence supporting the idea that deception is influenced by earnings management behavior. Thus, earnings management behavior is engaged in with the intent to deceive.

\section{CONCLUSIONS AND LIMITATIONS}

This study bridges the gap between qualitative and quantitative earnings management literature. The quantitative literature suggests that earnings management is widespread where the qualitative literature is heavy with nuances about the use and purpose of earnings management. I used a deception index to measure whether executives were being deceptive in relation to their earnings management use during annual conference calls. I expected to find the use of deception in conference calls limited to target firms, defined as those around the meet-orbeat benchmark.

Throughout the study, I find an association between executive deception and the earnings management measures. I find that CEO deception is primarily associated with RAM measures, whereas CFO deception is primarily associated with the discretionary accruals measure. This is indicative of the different earnings management strategies executives use in relation to their role within an organization.

The purpose of this study was to differentiate between traditional and deceptive earnings management, with the prediction that deceptive earnings management would be largely found in firms that are at the meet-or-beat earnings benchmark. Contrary to expectations, the evidence towards deceptive earnings management was found primarily in the non-target firm samples. This suggests that deceptive earnings management is widespread, beyond firms that have a discernable external motive.

The negative relationship between deception and abnormal production costs is also an interesting finding, as it suggests that deception is related to less production by firms. The 
deception may be caused by executives who are trying to cover up less expected demand for their products or a winding down of certain aspects of their businesses.

One limitation of the study is the bag-of-words textual analysis approach, which does not account for context within the transcript or document. In addition, there may be other reasons the executives were deceitful, which the models do not fully account for. Future research can further examine the deception model as it relates to earnings management and may be able to better pinpoint the types of words executives use to be deceptive. Other textual analysis approaches, beyond the bag-of-words approach, can also be used to study managerial deception. The relationship between deception and abnormally low production costs can also be examined further.

\section{REFERENCES}

Allee, K. D., \& Deangelis, M. D. (2015). The structure of voluntary disclosure narratives: Evidence from tone dispersion. Journal of Accounting Research, 53(2), 241-274. https://doi.org/10.1111/1475-679X.12072

Ball, R. (2013). Accounting informs investors and earnings management is rife: Two questionable beliefs. Accounting Horizons, 27(4), 847-853. https://doi.org/10.2308/acch10366

Bartov, E., \& Cohen, D. A. (2008). The "“ Numbers Game"” in the pre- and post-SarbanesOxley eras. Journal of Accounting, Auditing \& Finance, 505-534.

Becker, C. L., Defond, M. L., Jiambalvo, J., \& Subramanyam, K. R. (1998). The effect of audit quality on earnings management. Contemporary Accounting Research, 15(1), 1-24.

Bereskin, F. L., Hsu, P.-H., \& Rotenberg, W. (2018). The real effects of real earnings management: Evidence from innovation. Contemporary Accounting Research2, 35(1), 525558.

Bonacchi, M., Cipollini, F., \& Zarowin, P. (2018). Parents' use of subsidiaries to "push down" earnings management: Evidence from Italy. Contemporary Accounting Research, 35(3), 1332-1362. https://doi.org/10.1111/1911-3846.12330

Bruns, W. J., \& Merchant, K. A. (1990). The dangerous morality of managing earnings. Management Accounting, 72(2), 22. https://doi.org/DOI:

Burgstahler, D., \& Dichev, I. (1997). Earnings management to avoid earnings decreases and losses. Journal of Accounting and Economics, 24, 99-126.

Carlsson, S., \& Lamti, R. (2015). Tone management and earnings management: A UK evidence of abnormal tone in CEO letters and abnormal accruals. University of Gothenburg.

Chi, W., Lisic, L. L., \& Pevzner, M. (2011). Is enhanced audit quality associated with greater real earnings management? Accounting Horizons, 25(2), 315-335. https://doi.org/10.2308/acch-10025

Choi, A., Choi, J. H., \& Sohn, B. C. (2018). The joint effect of audit quality and legal regimes on the use of real earnings management: international evidence. Contemporary Accounting Research, 35(4), 2225-2257. https://doi.org/10.1111/1911-3846.12370

Cohen, D. A., Dey, A., \& Lys, T. (2008). Real and accrual-based earnings management in the Pre- and Post- Sarbanes Oxley Periods. The Accounting Review, 83(3), 757-787. https://doi.org/10.2308/accr.2008.83.3.757

Cohen, D. A., \& Zarowin, P. (2010). Accrual-based and real earnings management activities around seasoned equity offerings. Journal of Accounting and Economics, 50(1), 2-19. https://doi.org/doi.org/10.1016 
Commerford, B. P., Hatfield, R. C., \& Houston, R. W. (2018). The effect of real earnings management on auditor scrutiny of management's other financial reporting decisions. Accounting Review, 93(5), 145-163. https://doi.org/10.2308/accr-52032

Commerford, B. P., Hermanson, D. R., Houston, R. W., \& Peters, M. F. (2016). Real earnings management: A threat to auditor comfort? Auditing, 35(4), 39-56. https://doi.org/10.2308/ajpt-51405

Commerford, B. P., Hermanson, D. R., Houston, R. W., \& Peters, M. F. (2019). Auditor sensitivity to real earnings management: The importance of ambiguity and earnings context. Contemporary Accounting Research, 36(2), 1-22. https://doi.org/10.1111/1911-3846.12441

Dechow, P. M. (1994). Accounting \& Economics The role of accounting accruals. Journal of Accounting and Economics, 18, 3-42. https://doi.org/10.1016/0165-4101(94)90016-7

Dechow, P. M., Kothari, S. P., \& Watts, R. L. (1998). The relation between earnings and cash flows. Journal of Accounting and Economics, 25, 133-168.

Dechow, P. M., \& Skinner, D. J. (2000). Earnings management: Reconciling the views of accounting academics, practitioners, and regulators. Accounting Horizons, 14(2), 235-250. https://doi.org/10.2308/acch.2000.14.2.235

Dechow, P. M., Sloan, R. G., \& Sweeny, A. P. (1995). Detecting earnings management. The Accounting Review, 70(2), 193-225.

Feng, M., Li, C., McVay, S. E., \& Ashbaugh-Skaife, H. (2015). Does ineffective internal control over financial reporting affect a firm's operations? Evidence from firms' inventory management. The Accounting Review, 90(2), 529-557. https://doi.org/10.2308/accr-50909

Gunny, K. A. (2005). What are the consequences of real earnings management. https://doi.org/10.1063/1.1774702

Gunny, K. A. (2010). The relation between earnings management using real activities manipulation and future performance: Evidence from meeting earnings benchmarks. Contemporary Accounting Research, 27(3), 855-888. https://doi.org/10.1111/j.19113846.2010.01029.x

Healy, P. M. (1985). The effect of bonus chemes on acocunting decisions. Journal of Accounting and Economics, 7, 85-107. https://doi.org/10.1016/0165-4101(85)90029-1

Healy, P. M., \& Wahlen, J. M. (1999). A review of the earnings management literature and its implications for standard setting. Accounting Horizons, 13, 365-383.

Hope, O.-K., \& Wang, J. (2018). Management deception, big-bath accounting, and information asymmetry: Evidence from linguistic analysis. Accounting, Organizations and Society, (April 2017), 0-1. https://doi.org/10.1016/j.aos.2018.02.004

Jarvinen, T., \& Myllyma, E. (2016). Real earnings management before and after reporting SOX 404 material weaknesses. Accounting Horizons, 30(1), 119-141. https://doi.org/10.2308/acch-51310

Jones, J. J. (1991). Earnings Management During Import Relief Investigations.pdf. Journal of Accounting Research, 29(2), 193-228.

Kaplan, S. E. (2001). Ethically Related of by Observers Earnings Judgments. Journal of Business Ethics, 32(4), 285-298.

Khurana, I. K., Pereira, R., \& Zhang, E. X. (2018). Is real earnings smoothing harmful? Evidence from firm-specific stock price crash risk. Contemporary Accounting Research, 35(1), 558587. https://doi.org/10.1111/1911-3846.12353

Kim, Y., \& Park, M. S. (2014). Real activities manipulation and auditors' client-retention decisions. Accounting Review, 89(1), 367-401. https://doi.org/10.2308/accr-50586 
Klein, A. (2002). Audit committee, board of director characteristics, and earnings management. Journal of Accounting and Economics, 33(3), 375-400.

Kothari, S., Leone, A. J., \& Wasley, C. E. (2005). Performance Matched Discretionary Accrual Measures. Journal of Accounting and Economics, 39(1), 163-197.

Kothari, S. P., Mizik, N., \& Roychowdhury, S. (2016). Managing for the moment: The role of earnings management via real activities versus accruals in SEO valuation. Accounting Review, 91(2), 559-586. https://doi.org/10.2308/accr-51153

Larcker, D. F., \& Zakolyukina, A. A. (2012). Detecting deceptive discussions in conference calls. Journal of Accounting Research, 50(2), 495-540. https://doi.org/10.1111/j.1475679X.2012.00450.x

Legget, D. M., Parsons, L. M., \& Reitenga, A. L. (2016). Real earnings management and subsequent operating performance. IUP Journal of Operations Management, 15(4), 7-32.

Li, F. (2008). Annual report readability, current earnings, and earnings persistence. Journal of Accounting and Economics, 45(2-3), 221-247. https://doi.org/10.1016/j.jacceco.2008.02.003

Li, F. (2010). Textual analysis of corporate disclosures: A survey of the literature. Journal of Accounting Literature, 29, 143-165.

Liu, A. Z., Subramanyam, K. R., Zhang, J., \& Shi, C. (2018). Do firms manage earnings to influence credit ratings? Evidence from negative credit watch resolutions. Accounting Review, 93(3), 267-298. https://doi.org/10.2308/accr-51855

Lo, K., Ramos, F., \& Rogo, R. (2017). Earnings management and annual report readability. Journal of Accounting and Economics, 63(1), 1-25. https://doi.org/10.1016/j.jacceco.2016.09.002

Loughran, T., \& McDonald, B. (2011). When is a liability not a liability? Textual analysis, dictionaries, and 10-Ks. Journal of Finance, 66(1), 35-65. https://doi.org/10.1111/j.15406261.2010.01625.x

Loughran, T., \& McDonald, B. (2016). Textual analysis in accounting and finance: A survey. Journal of Accounting Research, 54(4), 1187-1230. https://doi.org/10.1111/1475679X.12123

Melloy, J. (2018, May 4). Tesla's Elon Musk defends his strange conference call performance, promises short "burn of the century." Retrieved from CNBC website: https://www.cnbc.com/2018/05/04/elon-musk-defends-his-strange-conference-callperformance-says-analysts-were-trying-to-justify-their-tesla-short-thesis.html

Merriam-Webster.com. (2020). "mislead." Retrieved June 16, 2020, from https://www.merriamwebster.com/dictionary/mislead

Mizik, N., \& Jacobson, R. (2008). Earnings inflation through accruals and real activity manipulation: Its prevalence at the time of an SEO and the financial market consequences. In SSRN Electronic Journal. https://doi.org/10.2139/ssrn.1031006

Nelson, M. W., Elliott, J. a, Tarpley, R. L., \& Gibbins, M. (2002). Evidence from auditors about managers' and auditors' earnings management decisions. The Accounting Review, 77, 175. https://doi.org/10.2308/accr.2002.77.s-1.175

Parfet, W. U. (2000). Accounting subjectivity and earnings management: A preparer perspective. Accounting Horizons, 14(4), 481-488. https://doi.org/10.2308/acch.2000.14.4.481

Pennebaker, J. W., Boyd, R. L., Jordan, K., \& Blackburn, K. (2015). The development and psychometric properties of LIWC2015. https://doi.org/10.1115/msec2014-3991

Press, E. G., \& Weintrop, J. B. (1990). Accounting-based constraints in public and private debt 
agreements: Their association with leverage and impact on accounting choice. Journal of Accounting and Economics, 12(1-3), 65-95.

Purda, L., \& Skillicorn, D. (2015). Accounting Variables, Deception, and a Bag of Words: Assessing the Tools of Fraud Detection. Contemporary Accounting Research, 32(3), 11931223. https://doi.org/10.1111/1911-3846.12089

Roychowdhury, S. (2006). Earnings management through real activities manipulation. Journal of Accounting and Economics, 42(3), 335-370. https://doi.org/10.1016/j.jacceco.2006.01.002

Schipper, K. (1989). Commentary on earnings mangement. Accounting Horizons, (December), 91-102.

Scott Asay, H. (2018). Horizon-induced optimism as a gateway to earnings management. Contemporary Accounting Research, 35(1), 7-30. https://doi.org/10.1111/1911-3846.12388

Shivakumar, L. (2000). Do firms mislead investors by overstating earnings before seasoned equity offerings? Journal of Accounting and Economics, 29(3), 339-371. https://doi.org/10.1016/S0165-4101(00)00026-4

Teoh, S. H., Welch, I. V. O., \& Wong, T. J. (1998). Earnings management and the long-run market performance of initial public offerings. The Journal of Finance, 43(6), 5-23. https://doi.org/10.1021/ed078p444

Zang, A. Y. (2012). Evidence on the trade-off between real activities manipulation and accrualbased earnings management. Accounting Review, 87(2), 675-703. https://doi.org/10.2308/accr-10196 


\begin{tabular}{|c|c|c|}
\hline \multicolumn{3}{|c|}{$\begin{array}{c}\text { APPENDIX A } \\
\text { Deceptive Word Categories }\end{array}$} \\
\hline Category & Abbreviation & Content \\
\hline $\begin{array}{l}\text { Reference to } \\
\text { General } \\
\text { Knowledge }\end{array}$ & REFGK & $\begin{array}{l}\text { everybody knows, everybody long knows, everybody } \\
\text { well knows, everybody would agree, everyone knows, } \\
\text { everyone long knows, everyone well knows, everyone } \\
\text { would agree, investors know, investors long know, } \\
\text { investors well know, investors would agree, others } \\
\text { know, others long know, others well know, others would } \\
\text { agree, shareholders know, shareholders long know, } \\
\text { shareholders well know, shareholders would agree, } \\
\text { stockholders know, stockholders long know, } \\
\text { stockholders well know, stockholders would agree, they } \\
\text { know, they long know, they well know, they would } \\
\text { agree, you folks know, you guys know, you know, you } \\
\text { long know, you well know, you would agree }\end{array}$ \\
\hline $\begin{array}{l}\text { Extreme } \\
\text { Positive } \\
\text { Emotions }\end{array}$ & XPOSEMOT & $\begin{array}{l}\text { amaz*, A-one, astonish*, awe-inspiring, awesome, } \\
\text { awful, bang-up, best, bless*, brillian*, by all odds, } \\
\text { careful*, challeng*, cherish*, confidence, confident, } \\
\text { confidently, convinc*, crack, cracking, dandy, deadly, } \\
\text { definite, definitely, delectabl*, delicious*, deligh*, } \\
\text { deucedly, devilishly, dynam*, eager*, emphatically, } \\
\text { enormous, excel*, excit*, exult, fab, fabulous*, } \\
\text { fantastic*, first-rate, flawless*, genuinely, glori*, } \\
\text { gorgeous*, grand, grande*, gratef*, great, groovy, hero*, } \\
\text { huge, illustrious, immense, in spades, in truth, } \\
\text { incredibl*, insanely, inviolable, keen*, luck, lucked, } \\
\text { lucki*, lucks, lucky, luscious, madly, magnific*, } \\
\text { marvellous, marvelous, neat*, nifty, outstanding, } \\
\text { peachy, perfect*, phenomenal, potent, privileg*, rattling, } \\
\text { redoubtable, rejoice, scrumptious*, secur*, sincer*, slap- } \\
\text { up, smashing, solid, splend*, strong*, substantial, } \\
\text { succeed*, success*, super, superb, superior*, suprem*, } \\
\text { swell, terrific*, thankf*, tiptop, topnotch, treasur*, } \\
\text { tremendous, triumph*, truly, truth*, unassailable, } \\
\text { unbelievable, unquestionably, vast, very good, } \\
\text { wonderf*, wondrous, wow*, yay, yays }\end{array}$ \\
\hline $\begin{array}{l}\text { Shareholder } \\
\text { Value }\end{array}$ & SV & $\begin{array}{l}\text { shareholder value, shareholder welfare, shareholder } \\
\text { well-being, value for our shareholders, value for } \\
\text { shareholders, stockholder value, stockholder welfare, } \\
\text { stockholder well-being, value for our stockholders, value } \\
\text { for stockholder, investor value, investor welfare, } \\
\text { investor well-being, value for our investors, value for } \\
\text { investors }\end{array}$ \\
\hline
\end{tabular}


Anxiety

Negations

Swear words

Extreme

negative

emotions
ANX

NEGATE

SWEAR 
unimaginable, unimportant, unlucky, unmanageable, unspeakable, unsuccessful*, untoward, unworthy, usurious, vehement, vexing, vicious*, victim*, vile, violat*, violent*, vulnerab*, washed-up, wicked*, withering, wonky, worst, worthless*, wretched, very bad

First-person pronouns impersonal pronouns
LWIC category "I": I, I'd, mine, my, etc.

THEY
LWIC category "They": Their*, them, they'd, etc. 


\begin{tabular}{|c|c|}
\hline \multicolumn{2}{|r|}{$\begin{array}{c}\text { APPENDIX B } \\
\text { Variable Definitions }\end{array}$} \\
\hline Variables & Definition \\
\hline DECP & $\begin{array}{l}\text { Standardized score of the aggregate of deceptive word categories, the } \\
\text { speaker is designated by CEO_DECP or CFO_DECP. }\end{array}$ \\
\hline TA & $\begin{array}{l}\text { Total accruals calculated by Earnings before extraordinary items and } \\
\text { discontinued operations less cash flow from operations }\end{array}$ \\
\hline IB & Earnings before extraordinary items and discontinued operations \\
\hline CASH & Operating Cash flows \\
\hline ASSETS & Total Assets \\
\hline REV & Revenue \\
\hline PPE & Property, plant, and equipment \\
\hline NA & Estimated Normal accruals estimated using coefficients from Model 1 \\
\hline AR & Accounts receivable \\
\hline DA & $\begin{array}{l}\text { Discretionary accruals calculated by scaled total accruals less estimated } \\
\text { normal accruals }\end{array}$ \\
\hline LEV & Total debt scaled by assets \\
\hline ROA & Return on assets is calculated by Net income divided by assets \\
\hline ASSETGROWTH & Change in total assets from the prior to the current year \\
\hline RESTATE & $\begin{array}{l}\text { Dummy variable - } 1 \text { if the current year financial statement has been } \\
\text { restated }\end{array}$ \\
\hline LOSS & Dummy variable - 1 if the firm reported a loss for the period, 0 otherwise \\
\hline NI & Net Income \\
\hline SALES & Sales \\
\hline COGS & $\begin{array}{l}\text { Estimated normal cost of goods sold, estimates using the coefficients from } \\
\text { model } 6\end{array}$ \\
\hline INV & Estimated normal change in inventory estimated using model 7 \\
\hline PROD & Estimated normal production costs using the coefficients form model 8 \\
\hline DISEXP & Discretionary expenses calculated using model 9 \\
\hline ABN_CFO & $\begin{array}{l}\text { Abnormal cash flows are calculated by subtracting the estimated cash } \\
\text { flows from the actual cash flows }\end{array}$ \\
\hline ABN_PROD & $\begin{array}{l}\text { Abnormal production costs are calculated by subtracting the estimated } \\
\text { production costs from the actual production costs }\end{array}$ \\
\hline ABN_DISEXP & $\begin{array}{l}\text { Abnormal discretionary expenses are calculated by subtracting the } \\
\text { estimated discretionary expense form the actual discretionary expenses }\end{array}$ \\
\hline RAM & $\begin{array}{l}\text { Real Activities management variable, ABN_CFO, ABN_PROD, } \\
\text { ABN_DISEXP, REM_INDEX }\end{array}$ \\
\hline
\end{tabular}




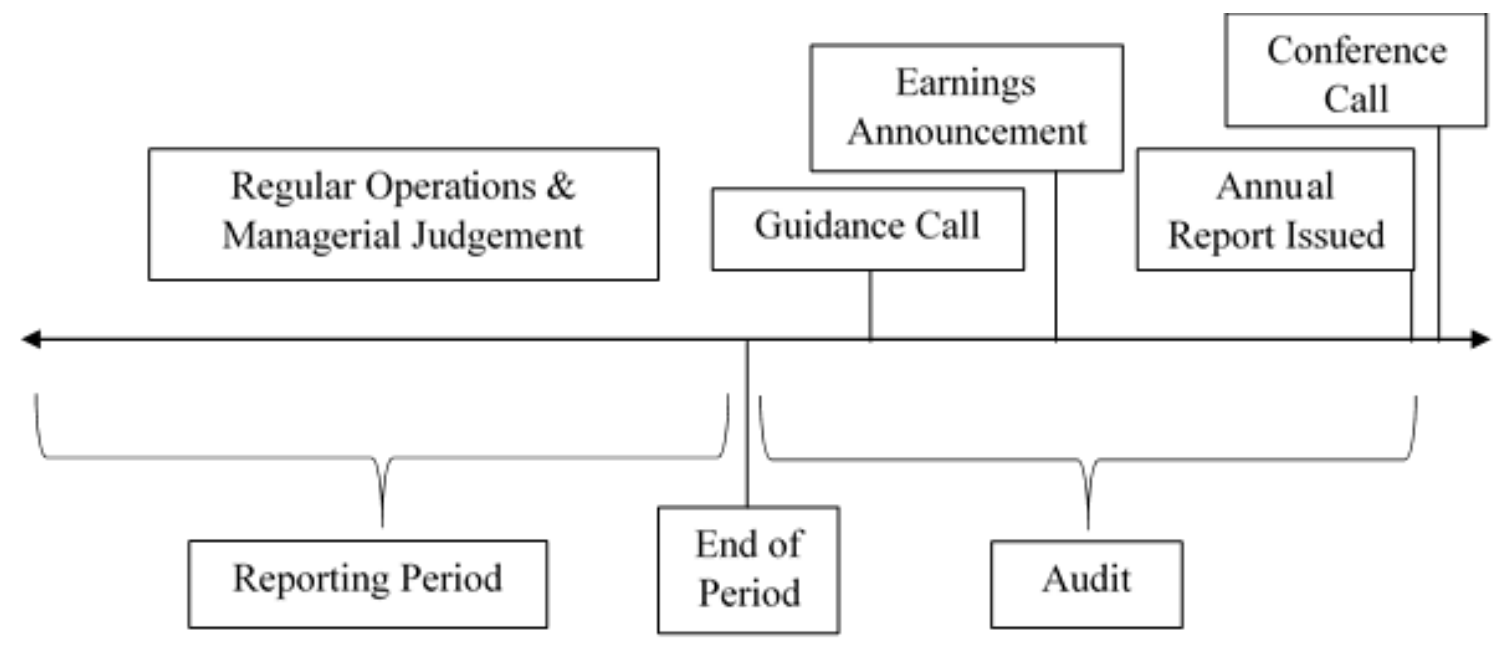

Figure 1: Reporting Period Timeline

Table 1

\begin{tabular}{ccc} 
Industry & CEO & CFO \\
\hline Mining & 602 & 538 \\
Construction & 109 & 121 \\
Manufacturing & 4633 & 4517 \\
Transportation & 531 & 547 \\
Wholesale & 337 & 323 \\
Retail & 563 & 577 \\
Services & $\underline{\mathbf{1 8 0 6}}$ & $\underline{\mathbf{1 8 1 9}}$ \\
Total & $\mathbf{8 5 8 1}$ & $\mathbf{8 4 4 2}$
\end{tabular}

This table presents the number of firms

present in each industry for the CEO and CFO samples. 
Table 2

Descriptive statistics for select variables

\begin{tabular}{|c|c|c|c|c|c|c|}
\hline Variable & Mean & Median & $\begin{array}{l}\text { Std. } \\
\text { Dev }\end{array}$ & Mean & Median & $\begin{array}{l}\text { Std. } \\
\text { Dev }\end{array}$ \\
\hline DECP & 0 & -0.5261 & 1 & 0 & -0.3305 & 1 \\
\hline DECP_X & 0 & 0.0369 & 1 & 0 & 0.0552 & 1 \\
\hline WORDCOUNT & 3489.46 & 3283 & 1881.64 & 2700.94 & 2438 & 1708.43 \\
\hline REFGK & 0.0463 & 0.02 & 0.08795 & 0.0337 & 0 & 0.08556 \\
\hline XPOSEMOT & 0.6748 & 0.63 & 0.33675 & & & \\
\hline ANX & 0.0815 & 0.06 & 0.09599 & & & \\
\hline NEGATE & & & & 0.4541 & 0.4 & 0.30983 \\
\hline SWEAR & & & & 0.0045 & 0 & 0.06982 \\
\hline XNEGEMOT & & & & 0.1083 & 0.08 & 0.11646 \\
\hline I & & & & 0.9233 & 0.84 & 0.54302 \\
\hline THEY & & & & 0.2433 & 0.18 & 0.26279 \\
\hline SV & 0.00879 & 0 & 0.0278 & 0.00566 & 0 & 0.01951 \\
\hline ROA & -0.0175 & 0.0371 & 0.24588 & -0.0116 & 0.038 & 0.23531 \\
\hline LEV & 0.5176 & 0.4982 & 0.2788 & 0.5188 & 0.5004 & 0.27694 \\
\hline LIABILITIES & 3024.78 & 475.978 & 8231.57 & 3374.37 & 513.303 & 9155.88 \\
\hline ASSETGROWTH & 0.1301 & 0.0439 & 0.70509 & 0.127 & 0.0445 & 0.69517 \\
\hline ASSETS & 4977.04 & 885.7 & 13784.1 & 5559.59 & 962.642 & 15366.8 \\
\hline LNASSETS & 6.8514 & 6.8983 & 1.96015 & 6.9399 & 6.9809 & 1.96177 \\
\hline SALES & 4187.8 & 802.46 & 11145.9 & 4672.25 & 844.536 & 12443.7 \\
\hline RESTATE & 0 & 0 & 0.069 & 0 & 0 & 0.07 \\
\hline LOSS & 0.31 & 0 & 0.463 & 0.3 & 0 & 0.459 \\
\hline DISEXP & 914.144 & 192.367 & 2673.4 & 1014.81 & 201.957 & 2959.38 \\
\hline DISSACC & -0.0446 & -0.0399 & 0.1458 & -0.045 & -0.0392 & 0.14198 \\
\hline ABN_CFO & 0 & 0.0047 & 0.13992 & 0 & 0.0037 & 0.13428 \\
\hline ABN_PROD & 0 & 0.0056 & 0.17927 & 0 & 0.0047 & 0.17887 \\
\hline ABN_DISEXP & 0 & -0.0197 & 0.30502 & 0 & -0.0191 & 0.29979 \\
\hline
\end{tabular}

Note: Refer to Appendix B for variable definitions 


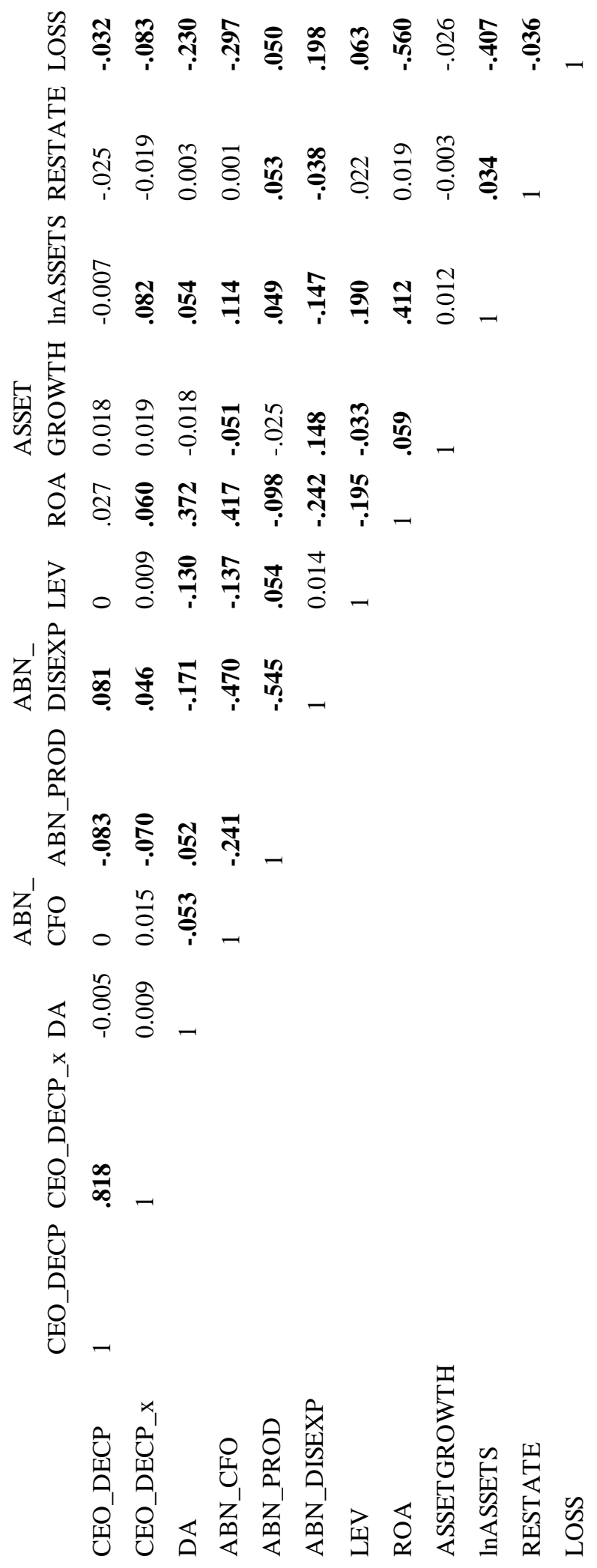




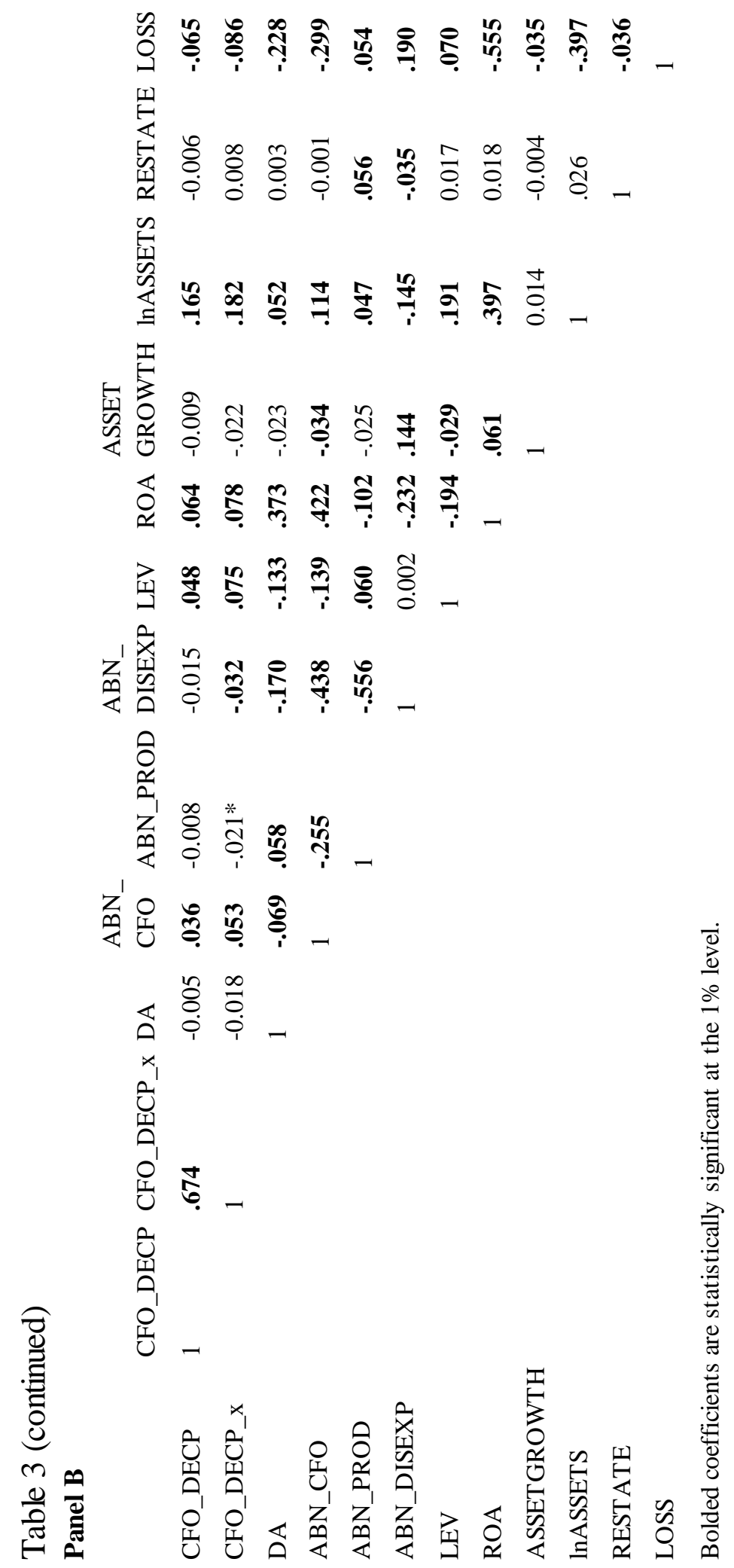




\section{Table 4}

This table depicts the results of hypothesis $1 \mathrm{a}, 1 \mathrm{~b}$, and $1 \mathrm{c}$, which tests the relationship between CEO deception and Discretionary accruals management. The dependent variables used were the CEO deception measures, CEO_DECP and CEO_DECP_X. H1A tests the full sample population. H1B and C split the sample and respectively test the target and nontarget firms. Target firms were defined in two ways, the first was if a firm had earnings per share within $\$ 0.03$ of last year's earnings per share. The suspect measure followed Roychowdhury (2006) and target firms were defined as those firms where net income scaled by assets is greater than or equal to zero but less than 0.005 . The coefficients are on the first line, and the $t-$ statistics are in the parentheses $* * * \mathrm{p}<0.01, * * \mathrm{p}<0.05, * \mathrm{p}<0.1$

\section{H1A - All Firms}

\begin{tabular}{|c|c|c|c|}
\hline & Pred. & CEO_DECP & $\begin{array}{c}\mathrm{CEO}_{-} \\
\mathrm{DECP} \_\mathrm{X}\end{array}$ \\
\hline Constant & & $\begin{array}{l}0.145 * * \\
(2.047)\end{array}$ & $\begin{array}{l}-0.153 * * \\
(-2.174)\end{array}$ \\
\hline DA & + & $\begin{array}{l}-0.103 \\
(-1.281)\end{array}$ & $\begin{array}{l}-0.013 \\
(-0.167)\end{array}$ \\
\hline LEV & + & $\begin{array}{l}-0.020 \\
(-0.491)\end{array}$ & $\begin{array}{l}-0.029 \\
(-0.694)\end{array}$ \\
\hline ROA & $?$ & $\begin{array}{l}0.60 \\
(1.009)\end{array}$ & $\begin{array}{l}-0.031 \\
(-0.530)\end{array}$ \\
\hline ASSETGROWTH & $?$ & $\begin{array}{l}0.022 \\
(1.464)\end{array}$ & $\begin{array}{l}0.023 \\
(1.525)\end{array}$ \\
\hline $\operatorname{lnASSETS}$ & $?$ & $\begin{array}{l}0.009 \\
(1.316)\end{array}$ & $\begin{array}{l}0.055^{* * *} \\
(8.119)\end{array}$ \\
\hline RESTATE & + & $\begin{array}{l}-0.391 * * \\
(-2.529)\end{array}$ & $\begin{array}{l}-0.358 * * \\
(-2.319)\end{array}$ \\
\hline LOSS & + & $\begin{array}{l}-0.043 \\
(-1.500)\end{array}$ & $\begin{array}{l}-0.103 * * * \\
(-3.583)\end{array}$ \\
\hline $\mathrm{n}$ & & 8581 & 8581 \\
\hline $\mathrm{R}^{2}$ & & 0.028 & 0.036 \\
\hline Industry FE & & Yes & Yes \\
\hline Year FE & & Yes & Yes \\
\hline
\end{tabular}


Table 4 (continued)

\begin{tabular}{|c|c|c|c|c|c|}
\hline & \multirow[b]{3}{*}{ Pred. } & \multicolumn{2}{|c|}{ H1B - EPS \$0.03 } & \multicolumn{2}{|c|}{ H1C - EPS \$0.03 } \\
\hline & & \multicolumn{2}{|c|}{$\mathrm{CEO}_{-}$} & \multicolumn{2}{|c|}{$\mathrm{CEO}_{-}$} \\
\hline & & CEO_DECP & DECP_X & CEO_DECP & DECP_X \\
\hline \multirow[t]{2}{*}{ Constant } & & 0.047 & -0.231 & $0.135^{*}$ & $-0.161 * *$ \\
\hline & & $(0.126)$ & $(-0.612)$ & $(1.862)$ & $(-2.23)$ \\
\hline \multirow[t]{2}{*}{ DA } & + & -0.525 & -0.711 & -0.093 & 0.004 \\
\hline & & $(-0.963)$ & $(-1.299)$ & $(-1.139)$ & $(0.054)$ \\
\hline \multirow[t]{2}{*}{ LEV } & + & $-0.532 * *$ & -0.445 & -0.003 & -0.015 \\
\hline & & $(-2.283)$ & $(-1.9)$ & $(-0.071)$ & $(-0.35)$ \\
\hline \multirow[t]{2}{*}{ ROA } & $?$ & 0.398 & 0.23 & 0.055 & -0.036 \\
\hline & & (1.207) & $(0.693)$ & $(0.902)$ & $(-0.601)$ \\
\hline \multirow[t]{2}{*}{ ASSETGROWTH } & $?$ & 0.035 & 0.018 & 0.02 & 0.021 \\
\hline & & $(0.341)$ & $(0.174)$ & $(1.31)$ & $(1.387)$ \\
\hline \multirow[t]{2}{*}{$\operatorname{lnASSETS}$} & $?$ & -0.008 & 0.028 & 0.01 & 0.056 \\
\hline & & $(-0.246)$ & $(0.807)$ & $(1.49)$ & $(8.106)$ \\
\hline \multirow[t]{2}{*}{ RESTATE } & + & 0.125 & -0.183 & $-0.442 * *$ & $-0.367 * *$ \\
\hline & & $(0.251)$ & $(-0.366)$ & $(-2.71)$ & $(-2.258)$ \\
\hline \multirow[t]{2}{*}{ LOSS } & + & $0.404 * *$ & 0.213 & $-0.056^{*}$ & -0.112 \\
\hline & & $(2.556)$ & (1.343) & $(-1.9)$ & $(-3.813)$ \\
\hline $\mathrm{n}$ & & 305 & 305 & 8276 & 8276 \\
\hline $\mathrm{R}^{2}$ & & 0.088 & 0.083 & 0.029 & 0.037 \\
\hline Industry FE & & Yes & Yes & Yes & Yes \\
\hline Year FE & & Yes & Yes & Yes & Yes \\
\hline
\end{tabular}


Table 4 (continued)

\begin{tabular}{|c|c|c|c|c|c|}
\hline & \multirow[b]{3}{*}{ Pred. } & \multicolumn{2}{|c|}{ H1B - Suspect } & \multicolumn{2}{|c|}{ H1C - Suspect } \\
\hline & & \multicolumn{2}{|c|}{ CEO } & & \multirow{2}{*}{$\begin{array}{c}\mathrm{CEO}_{-} \\
\mathrm{DECP}_{-} \mathrm{X}\end{array}$} \\
\hline & & CEO_DECP & DECP_X & CEO_DECP & \\
\hline \multirow[t]{2}{*}{ Constant } & & -0.052 & -0.16 & $0.136^{*}$ & $-0.166^{* *}$ \\
\hline & & $(-0.097)$ & $(-0.287)$ & (1.906) & $(-2.324)$ \\
\hline \multirow[t]{2}{*}{ DA } & + & -1.453 & -0.459 & -0.09 & -0.005 \\
\hline & & $(-1.207)$ & $(-0.364)$ & $(-1.123)$ & $(-0.067)$ \\
\hline \multirow[t]{2}{*}{ LEV } & + & 0.578 & 0.555 & -0.021 & -0.031 \\
\hline & & $(1.361)$ & (1.249) & $(-0.508)$ & $(-0.737)$ \\
\hline \multirow[t]{2}{*}{ ROA } & $?$ & 2.634 & 1.644 & 0.047 & -0.044 \\
\hline & & (1.299) & $(0.775)$ & $(0.78)$ & $(-0.741)$ \\
\hline \multirow[t]{2}{*}{ ASSETGROWTH } & $?$ & -0.037 & -0.02 & $0.062 * *$ & $0.059 * *$ \\
\hline & & $(-1.618)$ & $(-0.82)$ & $(2.784)$ & $(2.649)$ \\
\hline \multirow[t]{2}{*}{$\operatorname{lnASSETS}$} & $?$ & 0.016 & 0.073 & 0.009 & 0.055 \\
\hline & & $(0.272)$ & $(1.225)$ & (1.289) & $(8.051)$ \\
\hline \multirow[t]{2}{*}{ RESTATE } & + & 0.54 & -0.53 & $-0.417 * *$ & $-0.365^{*}$ \\
\hline & & $(0.525)$ & $(-0.493)$ & $(-2.663)$ & $(-2.342)$ \\
\hline \multirow[t]{2}{*}{ LOSS } & + & 0.165 & 0.034 & -0.047 & -0.108 \\
\hline & & $(0.398)$ & $(0.078)$ & $(-1.62)$ & $(-3.717)$ \\
\hline $\mathrm{n}$ & & 151 & 151 & 8430 & 8430 \\
\hline $\mathrm{R}^{2}$ & & 0.114 & 0.122 & 0.03 & 0.037 \\
\hline Industry FE & & Yes & Yes & Yes & Yes \\
\hline Year FE & & Yes & Yes & Yes & Yes \\
\hline
\end{tabular}




\section{Table 5}

This table depicts the results of hypothesis $2 \mathrm{a}, 2 \mathrm{~b}$, and $2 \mathrm{c}$, which tests the relationship between CFO deception and discretionary accruals management. The dependent variables used were the CFO deception measures, CFO_DECP and CFO_DECP_X. H2A tests the full sample population. H2B and C split the sample and respectively test the target and non-target firms. Target firms were defined in two ways, the first was if a firm had earnings per share within $\$ 0.03$ of last year's earnings per share. The suspect measure followed Roychowdhury (2006) and target firms were defined as those firms where net income scaled by assets is greater than or equal to zero but less than 0.005 . The coefficients are on the first line, and the t-statistics are in the parentheses $* * * \mathrm{p}<0.01, * * \mathrm{p}<0.05, * \mathrm{p}<0.1$

\section{H2A - All Firms}

\begin{tabular}{|c|c|c|c|}
\hline & Pred. & CFO_DECP & CFO_DECP_X \\
\hline \multirow[t]{2}{*}{ Constant } & & $-0.674 * * *$ & $-0.749 * * *$ \\
\hline & & $(-9.539)$ & $(-10.780)$ \\
\hline \multirow[t]{2}{*}{ DA } & + & -0.128 & $-0.232 * *$ \\
\hline & & $(-1.549)$ & $(-2.851)$ \\
\hline \multirow[t]{2}{*}{ LEV } & + & 0.041 & $0.117 * *$ \\
\hline & & $(0.971)$ & $(2.838)$ \\
\hline \multirow[t]{2}{*}{$\mathrm{ROA}$} & $?$ & 0.045 & $0.101 *$ \\
\hline & & $(0.729)$ & $(1.665)$ \\
\hline \multirow[t]{2}{*}{ ASSETGROWTH } & $?$ & -0.014 & $-0.033 * *$ \\
\hline & & $(-0.926)$ & $(-2.150)$ \\
\hline \multirow[t]{2}{*}{ lnASSETS } & $?$ & $0.092 * * *$ & $0.104 * * *$ \\
\hline & & (12.713) & $(15.640)$ \\
\hline \multirow[t]{2}{*}{ RESTATE } & + & -0.173 & 0.028 \\
\hline & & $(-1.137)$ & $(0.184)$ \\
\hline \multirow[t]{2}{*}{ LOSS } & + & 0.020 & -0.031 \\
\hline & & $(0.685)$ & $(-1.096)$ \\
\hline $\mathrm{n}$ & & 8442 & 8442 \\
\hline $\mathrm{R}^{2}$ & & 0.041 & 0.073 \\
\hline Industry FE & & Yes & Yes \\
\hline Year FE & & Yes & Yes \\
\hline
\end{tabular}

Table 5 (continued)

H2B - EPS \$0.03

$\mathrm{CFO}_{-}$ DECP
$\mathrm{CFO}$ DECP_X
H2C - EPS \$0.032

$\mathrm{CFO}_{-} \quad \mathrm{CFO}_{-}$
DECP DECP_X 


\begin{tabular}{|c|c|c|c|c|c|}
\hline Constant & & $\begin{array}{l}-0.314 \\
(-0.849)\end{array}$ & $\begin{array}{l}-0.504 \\
(-1.235)\end{array}$ & $\begin{array}{l}-0.698 * * * \\
(-9.651)\end{array}$ & $\begin{array}{l}-0.773 * * * \\
(-10.924)\end{array}$ \\
\hline DA & + & $\begin{array}{l}0.032 \\
(0.052)\end{array}$ & $\begin{array}{l}0.672 \\
(1.024)\end{array}$ & $\begin{array}{l}-0.135 \\
(-1.618)\end{array}$ & $\begin{array}{l}-0.260 * * \\
(-3.176)\end{array}$ \\
\hline LEV & + & $\begin{array}{l}-0.042 \\
(-0.170)\end{array}$ & $\begin{array}{l}0.595 * * \\
(2.157)\end{array}$ & $\begin{array}{l}0.044 \\
(1.035)\end{array}$ & $\begin{array}{l}0.103 * * \\
(2.476)\end{array}$ \\
\hline ROA & $?$ & $\begin{array}{l}-0.151 \\
(-0.421)\end{array}$ & $\begin{array}{l}-0.215 \\
(-0.555)\end{array}$ & $\begin{array}{l}0.050 \\
(0.794)\end{array}$ & $\begin{array}{l}0.110 * \\
(1.796)\end{array}$ \\
\hline ASSETGROWTH & $?$ & $\begin{array}{l}-0.076 \\
(-0.715)\end{array}$ & $\begin{array}{l}-0.132 \\
(-1.149)\end{array}$ & $\begin{array}{l}-0.013 \\
(-0.805)\end{array}$ & $\begin{array}{l}-0.029 * \\
(-1.885)\end{array}$ \\
\hline lnASSETS & $?$ & $\begin{array}{l}0.071 \\
(2.022)\end{array}$ & $\begin{array}{l}0.065^{*} \\
(1.660)\end{array}$ & $\begin{array}{l}0.094 * * * \\
(13.676)\end{array}$ & $\begin{array}{l}0.106^{* * *} \\
(15.790)\end{array}$ \\
\hline RESTATE & + & $\begin{array}{l}0.231 \\
(0.408)\end{array}$ & $\begin{array}{l}-0.119 \\
(-0.162)\end{array}$ & $\begin{array}{l}-0.200 \\
(-1.269)\end{array}$ & $\begin{array}{l}0.032 \\
(0.209)\end{array}$ \\
\hline LOSS & + & $\begin{array}{l}-0.074 \\
(-0.468)\end{array}$ & $\begin{array}{l}-0.257 \\
(-1.471)\end{array}$ & $\begin{array}{l}0.024 \\
(0.826)\end{array}$ & $\begin{array}{l}-0.023 \\
(-0.784)\end{array}$ \\
\hline $\mathrm{n}$ & & 292 & 292 & 8150 & 8150 \\
\hline $\mathrm{R}^{2}$ & & 0.062 & 0.102 & 0.042 & 0.074 \\
\hline Industry FE & & Yes & Yes & Yes & Yes \\
\hline Year FE & & Yes & Yes & Yes & Yes \\
\hline
\end{tabular}


Table 5 (continued)

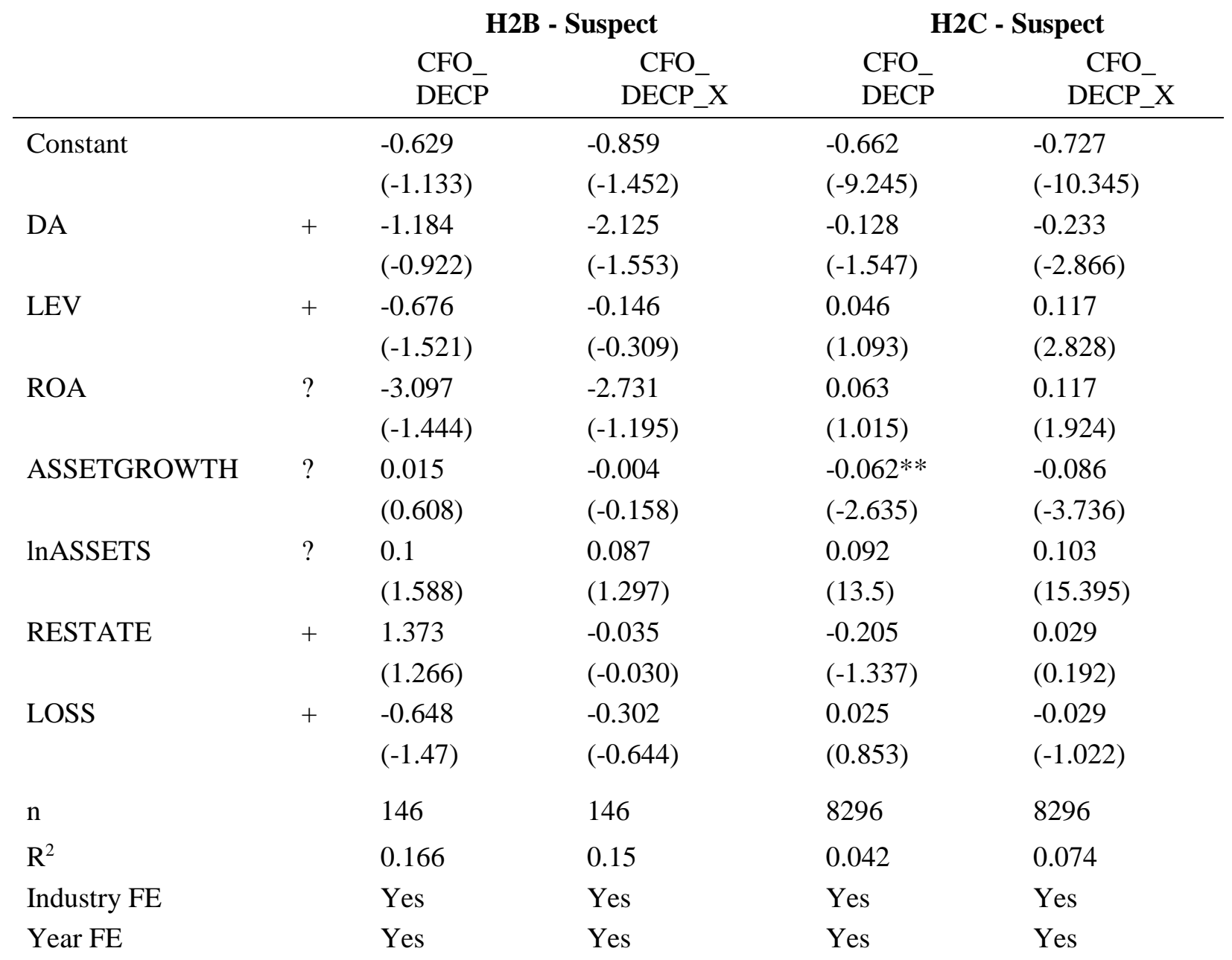




\section{Table 6.1}

This table depicts the results of hypothesis $3 a, 3 b$, and 3c, which tests the relationship between CEO deception and abnormal cashflows (ABN_CFO). The dependent variables used were the CEO deception measures, CEO_DECP and CEO_DECP_X. H3A tests the full sample population. H3B and C split the sample and respectively test the target and non-target firms. Target firms were defined in two ways, the first was if a firm had earnings per share within $\$ 0.03$ of last year's earnings per share. The suspect measure followed Roychowdhury (2006) and target firms were defined as those firms where net income scaled by assets is greater than or equal to zero but less than 0.005 . The coefficients are on the first line, and the t-statistics are in the parentheses $* * * \mathrm{p}<0.01, * * \mathrm{p}<0.05, * \mathrm{p}<0.1$

H3A - All Firms

\begin{tabular}{|c|c|c|c|}
\hline & Pred. & CEO_DECP & CEO_DECP_X \\
\hline \multirow[t]{2}{*}{ Constant } & & $0.148 * *$ & $-0.15 * *$ \\
\hline & & $(2.092)$ & $(-2.125)$ \\
\hline \multirow[t]{2}{*}{ ABN_CFO } & + & -0.103 & -0.072 \\
\hline & & $(-1.207)$ & $(-0.854)$ \\
\hline \multirow[t]{2}{*}{ LEV } & + & -0.021 & -0.03 \\
\hline & & $(-0.507)$ & $(-0.723)$ \\
\hline \multirow[t]{2}{*}{ ROA } & $?$ & 0.059 & -0.019 \\
\hline & & $(0.986)$ & $(-0.312)$ \\
\hline \multirow[t]{2}{*}{ ASSETGROWTH } & $?$ & 0.022 & 0.022 \\
\hline & & $(1.414)$ & $(1.456)$ \\
\hline \multirow[t]{2}{*}{ lnASSETS } & $?$ & 0.009 & $0.055 * * *$ \\
\hline & & (1.394) & (8.119) \\
\hline \multirow[t]{2}{*}{ RESTATE } & + & -0.392 & $-0.359 * *$ \\
\hline & & $(-2.534)$ & $(-2.325)$ \\
\hline \multirow[t]{2}{*}{ LOSS } & + & -0.045 & $-0.106 * * *$ \\
\hline & & $(-1.561)$ & $(-3.653)$ \\
\hline \multicolumn{2}{|l|}{$\mathrm{n}$} & 8581 & 8581 \\
\hline \multicolumn{2}{|l|}{$\mathrm{R}^{2}$} & 0.028 & 0.036 \\
\hline \multicolumn{2}{|l|}{ Industry FE } & Yes & Yes \\
\hline \multicolumn{2}{|l|}{ Year FE } & Yes & Yes \\
\hline
\end{tabular}


Table 6.1 (continued)

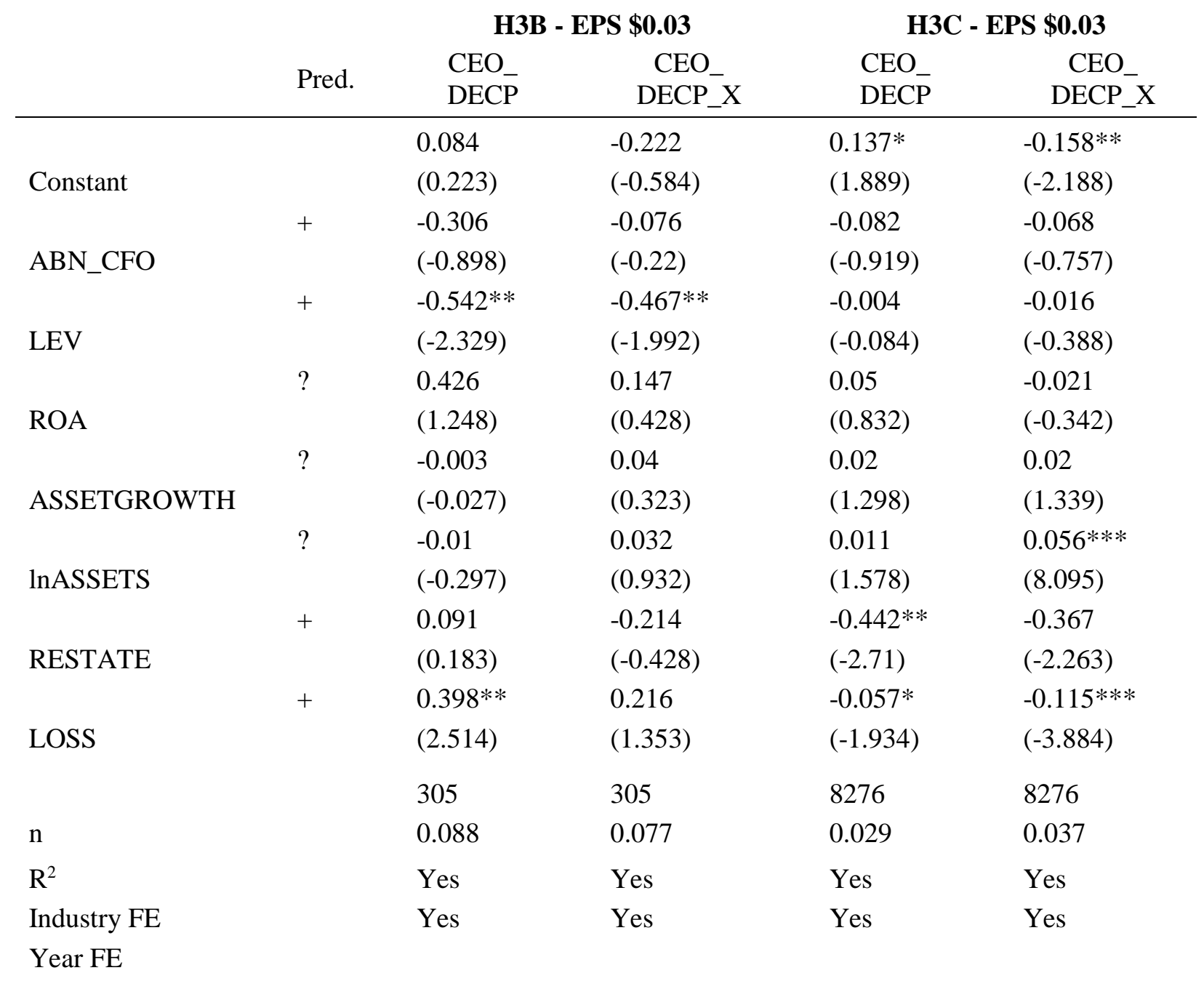


Table 6.1 (continued)

\begin{tabular}{|c|c|c|c|c|c|}
\hline & \multirow[b]{2}{*}{ Pred. } & \multicolumn{2}{|c|}{ H3B - Suspect } & \multicolumn{2}{|c|}{ H3C - Suspect } \\
\hline & & $\begin{array}{l}\mathrm{CEO}_{-} \\
\mathrm{DECP}^{-}\end{array}$ & $\begin{array}{c}\mathrm{CEO}_{-} \\
\mathrm{DECP}_{-} \mathrm{X}\end{array}$ & $\begin{array}{l}\mathrm{CEO}_{-} \\
\mathrm{DECP}^{-}\end{array}$ & $\begin{array}{c}\mathrm{CEO}_{-} \\
\text {DECP_X }\end{array}$ \\
\hline \multirow[t]{2}{*}{ Constant } & & 0.033 & -0.082 & $0.14^{*}$ & $-0.162 * *$ \\
\hline & & $(0.062)$ & $(-0.147)$ & (1.957) & $(-2.27)$ \\
\hline \multirow[t]{2}{*}{ ABN_CFO } & + & $2.262 * *$ & 1.632 & -0.099 & -0.067 \\
\hline & & $(2.083)$ & (1.43) & $(-1.154)$ & $(-0.783)$ \\
\hline \multirow[t]{2}{*}{ LEV } & + & 0.569 & 0.591 & -0.022 & -0.032 \\
\hline & & (1.375) & $(1.361)$ & $(-0.526)$ & $(-0.768)$ \\
\hline \multirow[t]{2}{*}{ ROA } & $?$ & 2.305 & 1.444 & 0.048 & -0.03 \\
\hline & & (1.148) & $(0.685)$ & $(0.794)$ & $(-0.508)$ \\
\hline \multirow[t]{2}{*}{ ASSETGROWTH } & $?$ & -0.036 & -0.019 & $0.061 * *$ & $0.057 * *$ \\
\hline & & $(-1.565)$ & $(-0.816)$ & $(2.688)$ & $(2.537)$ \\
\hline \multirow[t]{2}{*}{ lnASSETS } & $?$ & 0.03 & 0.076 & 0.009 & $0.055^{* * *}$ \\
\hline & & $(0.557)$ & (1.332) & (1.345) & $(8.037)$ \\
\hline \multirow[t]{2}{*}{ RESTATE } & + & 0.488 & -0.541 & -0.418 & $-0.366 * *$ \\
\hline & & $(0.48)$ & $(-0.508)$ & $(-2.669)$ & $(-2.348)$ \\
\hline \multirow[t]{2}{*}{ LOSS } & + & 0.049 & -0.015 & $-0.049 *$ & $-0.111 * * *$ \\
\hline & & $(0.121)$ & $(-0.034)$ & $(-1.685)$ & $(-3.784)$ \\
\hline $\mathrm{n}$ & & 151 & 151 & 8430 & 8430 \\
\hline $\mathrm{R}^{2}$ & & 0.133 & 0.134 & 0.03 & 0.037 \\
\hline Industry FE & & Yes & Yes & Yes & Yes \\
\hline Year FE & & Yes & Yes & Yes & Yes \\
\hline
\end{tabular}




\section{Table 6.2}

This table depicts the results of hypothesis $3 a, 3 b$, and 3c, which tests the relationship between CEO deception and abnormal production (ABN_PROD). The dependent variables used were the CEO deception measures, CEO_DECP and CEO_DECP_X. H3A tests the full sample population. H3B and C split the sample and respectively test the target and non-target firms. Target firms were defined in two ways, the first was if a firm had earnings per share within $\$ 0.03$ of last year's earnings per share. The suspect measure followed Roychowdhury (2006) and target firms were defined as those firms where net income scaled by assets is greater than or equal to zero but less than 0.005 . The coefficients are on the first line, and the t-statistics are in the parentheses $* * * \mathrm{p}<0.01, * * \mathrm{p}<0.05, * \mathrm{p}<0.1$

\section{H3A - All Firms}

Pred. CEO_DECP CEO_DECP_X

$\begin{array}{llll}\text { Constant } & & 0.11 & -0.183 * * \\ & & (1.564) & -2.597 \\ \text { ABN_PROD } & + & -0.455^{* * *} & -0.407 * * * \\ \text { LEV } & + & -7.595) & -6.805 \\ & & -0.019 & -0.028 \\ \text { ROA } & ? & -0.008 & -0.679 \\ & & (-0.15) & -0.074 \\ \text { ASSETGROWTH } & ? & 0.021 & -1.316 \\ & & (1.388) & 0.021 \\ \text { lnASSETS } & ? & 0.015 * * & 1.414 \\ & & (2.21) & 0.059 * * * \\ \text { RESTATE } & + & -0.329 * * & 8.837 \\ \text { LOSS } & & (-2.128) & -0.302 * \\ & + & -0.037 & -1.961 \\ \text { R } & & (-1.283) & -0.099 * * * \\ \text { Industry FE } & & -3.449 \\ \text { Year FE } & & 8581 & \\ \text { n } & & 0.035 & 8581 \\ & & \text { Yes } & 0.041 \\ & & \text { Yes } & \text { Yes } \\ & & & \end{array}$


Table 6.2 (continued)

\begin{tabular}{|c|c|c|c|c|c|}
\hline & \multirow[b]{2}{*}{ Pred. } & \multicolumn{2}{|c|}{ H3B - EPS \$0.03 } & \multicolumn{2}{|c|}{ H3C - EPS \$0.03 } \\
\hline & & $\begin{array}{l}\mathrm{CEO}_{-} \\
\mathrm{DECP}^{-}\end{array}$ & $\begin{array}{c}\mathrm{CEO}_{-} \\
\text {DECP_X }\end{array}$ & $\begin{array}{l}\mathrm{CEO}_{-} \\
\mathrm{DECP}^{-}\end{array}$ & $\begin{array}{c}\mathrm{CEO}_{-} \\
\text {DECP_X }\end{array}$ \\
\hline Constant & & $\begin{array}{l}0.000 \\
(-0.001)\end{array}$ & $\begin{array}{l}-0.274 \\
(-0.728)\end{array}$ & $\begin{array}{l}0.101 \\
(1.395)\end{array}$ & $\begin{array}{l}-0.19 * * \\
(-2.638)\end{array}$ \\
\hline ABN_PROD & + & $\begin{array}{l}-0.595 * * \\
(-2.185)\end{array}$ & $\begin{array}{l}-0.535^{*} \\
(-1.95)\end{array}$ & $\begin{array}{l}-0.452 * * * \\
(-7.352)\end{array}$ & $\begin{array}{l}-0.406^{* * *} \\
(-6.619)\end{array}$ \\
\hline LEV & + & $\begin{array}{l}-0.542^{* *} \\
(-2.35)\end{array}$ & $\begin{array}{l}-0.462 * * \\
(-1.987)\end{array}$ & $\begin{array}{l}-0.002 \\
(-0.036)\end{array}$ & $\begin{array}{l}-0.015 \\
(-0.349)\end{array}$ \\
\hline ROA & $?$ & $\begin{array}{l}0.314 \\
(0.992)\end{array}$ & $\begin{array}{l}0.117 \\
(0.368)\end{array}$ & $\begin{array}{l}-0.013 \\
(-0.219)\end{array}$ & $\begin{array}{l}-0.076 \\
(-1.322)\end{array}$ \\
\hline ASSETGROWTH & $?$ & $\begin{array}{l}0.06 \\
(0.612)\end{array}$ & $\begin{array}{l}0.053 \\
(0.541)\end{array}$ & $\begin{array}{l}0.019 \\
(1.223)\end{array}$ & $\begin{array}{l}0.019 \\
(1.268)\end{array}$ \\
\hline lnASSETS & $?$ & $\begin{array}{l}-0.003 \\
(-0.079)\end{array}$ & $\begin{array}{l}0.035 \\
(1.036)\end{array}$ & $\begin{array}{l}0.016 * * \\
(2.356)\end{array}$ & $\begin{array}{l}0.061 * * * \\
(8.788)\end{array}$ \\
\hline RESTATE & + & $\begin{array}{l}0.141 \\
(0.286)\end{array}$ & $\begin{array}{l}-0.178 \\
(-0.357)\end{array}$ & $\begin{array}{l}-0.375^{* *} \\
(-2.307)\end{array}$ & $\begin{array}{l}-0.308 * \\
(-1.898)\end{array}$ \\
\hline LOSS & + & $\begin{array}{l}0.429 * * \\
(2.728)\end{array}$ & $\begin{array}{l}0.238 \\
(1.498)\end{array}$ & $\begin{array}{l}-0.05^{*} \\
(-1.704)\end{array}$ & $\begin{array}{l}-0.108 * * * \\
(-3.704)\end{array}$ \\
\hline $\mathrm{n}$ & & 305 & 305 & 8276 & 8276 \\
\hline $\mathrm{R}^{2}$ & & 0.1 & 0.089 & 0.035 & 0.042 \\
\hline Industry FE & & Yes & Yes & Yes & Yes \\
\hline Year FE & & Yes & Yes & Yes & Yes \\
\hline
\end{tabular}


Table 6.2 (continued)

\begin{tabular}{|c|c|c|c|c|c|}
\hline \multirow{3}{*}{ Constant } & \multirow[b]{2}{*}{ Pred. } & \multicolumn{2}{|c|}{ H3B - Suspect } & \multicolumn{2}{|c|}{ H3C - Suspect } \\
\hline & & $\begin{array}{l}\mathrm{CEO}_{-} \\
\mathrm{DECP}\end{array}$ & $\mathrm{CEO}_{\text {DECP_X }}$ & $\begin{array}{l}\mathrm{CEO}_{-} \\
\mathrm{DECP}\end{array}$ & $\mathrm{CEO}_{\mathrm{DECP}_{-} \mathrm{X}}$ \\
\hline & & $\begin{array}{l}-0.242 \\
(-0.461)\end{array}$ & $\begin{array}{l}-0.286 \\
(-0.519)\end{array}$ & $\begin{array}{l}0.104 \\
(1.455)\end{array}$ & $\begin{array}{l}-0.194 * * \\
(-2.718)\end{array}$ \\
\hline ABN_PROD & + & $\begin{array}{l}-1.006 * * \\
(-2.527)\end{array}$ & $\begin{array}{l}-0.773 * \\
(-1.844)\end{array}$ & $\begin{array}{l}-0.438 * * * \\
(-7.208)\end{array}$ & $\begin{array}{l}-0.393 * * * \\
(-6.501)\end{array}$ \\
\hline LEV & + & $\begin{array}{l}0.488 \\
(1.197)\end{array}$ & $\begin{array}{l}0.534 \\
(1.243)\end{array}$ & $\begin{array}{l}-0.02 \\
(-0.473)\end{array}$ & $\begin{array}{l}-0.03 \\
(-0.731)\end{array}$ \\
\hline ROA & $?$ & $\begin{array}{l}2.609 \\
(1.311)\end{array}$ & $\begin{array}{l}1.666 \\
(0.795)\end{array}$ & $\begin{array}{l}-0.017 \\
(-0.291)\end{array}$ & $\begin{array}{l}-0.083 \\
(-1.465)\end{array}$ \\
\hline ASSETGROWTH & $?$ & $\begin{array}{l}-0.036 \\
(-1.616)\end{array}$ & $\begin{array}{l}-0.02 \\
(-0.849)\end{array}$ & $\begin{array}{l}0.06 * * \\
(2.666)\end{array}$ & $\begin{array}{l}0.055^{* *} \\
(2.484)\end{array}$ \\
\hline $\operatorname{lnASSETS}$ & $?$ & $\begin{array}{l}0.058 \\
(1.066)\end{array}$ & $\begin{array}{l}0.097 * \\
(1.691)\end{array}$ & $\begin{array}{l}0.014 * * \\
(2.12)\end{array}$ & $\begin{array}{l}0.059 * * * \\
(8.722)\end{array}$ \\
\hline RESTATE & + & $\begin{array}{l}0.428 \\
(0.424)\end{array}$ & $\begin{array}{l}-0.587 \\
(-0.553)\end{array}$ & $\begin{array}{l}-0.356 * * \\
(-2.273)\end{array}$ & $\begin{array}{l}-0.31 * * \\
(-1.992)\end{array}$ \\
\hline LOSS & + & $\begin{array}{l}0.091 \\
(0.227)\end{array}$ & $\begin{array}{l}0.016 \\
(0.038)\end{array}$ & $\begin{array}{l}-0.041 \\
(-1.403)\end{array}$ & $\begin{array}{l}-0.104 * * * \\
(-3.58)\end{array}$ \\
\hline $\mathrm{n}$ & & 151 & 151 & 8430 & 8430 \\
\hline $\mathrm{R}^{2}$ & & 0.146 & 0.143 & 0.035 & 0.041 \\
\hline Industry FE & & Yes & Yes & Yes & Yes \\
\hline Year FE & & Yes & Yes & Yes & Yes \\
\hline
\end{tabular}




\section{Table 6.3}

This table depicts the results of hypothesis $3 \mathrm{a}, 3 \mathrm{~b}$, and 3c, which tests the relationship between CEO deception and abnormal discretionary expenses (ABN_DISEXP). The dependent variables used were the CEO deception measures, CEO_DECP and CEO_DECP_X. H3A tests the full sample population. H3B and C split the sample and respectively test the target and non-target firms. Target firms were defined in two ways, the first was if a firm had earnings per share within $\$ 0.03$ of last year's earnings per share. The suspect measure followed Roychowdhury (2006) and target firms were defined as those firms where net income scaled by assets is greater than or equal to zero but less than 0.005 . The coefficients are on the first line, and the t-statistics are in the parentheses $* * * \mathrm{p}<0.01, * * \mathrm{p}<0.05, * \mathrm{p}<0.1$

\section{H3A - All Firms}

\begin{tabular}{|c|c|c|c|}
\hline & Pred. & CEO_DECP & CEO_DECP_X \\
\hline \multirow[t]{2}{*}{ Constant } & & $0.129 *$ & $-0.164 * *$ \\
\hline & & $(1.831)$ & $(-2.338)$ \\
\hline \multirow[t]{2}{*}{ ABN_DISEXP } & + & $0.315^{* * *}$ & $0.239 * * *$ \\
\hline & & $(8.6)$ & $(6.541)$ \\
\hline \multirow[t]{2}{*}{ LEV } & + & -0.012 & -0.024 \\
\hline & & $(-0.3)$ & $(-0.568)$ \\
\hline \multirow[t]{2}{*}{ ROA } & $?$ & $0.114 * *$ & 0.025 \\
\hline & & $(2.002)$ & $(0.435)$ \\
\hline \multirow[t]{2}{*}{ ASSETGROWTH } & $?$ & 0.001 & 0.006 \\
\hline & & $(0.073)$ & $(0.426)$ \\
\hline \multirow[t]{2}{*}{ lnASSETS } & $?$ & $0.012 *$ & $0.057 * * *$ \\
\hline & & $(1.78)$ & $(8.438)$ \\
\hline \multirow[t]{2}{*}{ RESTATE } & + & $-0.35^{* *}$ & $-0.327 * *$ \\
\hline & & $(-2.271)$ & $(-2.122)$ \\
\hline \multirow[t]{2}{*}{ LOSS } & + & $-0.06^{* *}$ & $-0.117 * * *$ \\
\hline & & $(-2.062)$ & $(-4.054)$ \\
\hline $\mathrm{n}$ & & 8581 & 8581 \\
\hline $\mathrm{R}^{2}$ & & 0.037 & 0.041 \\
\hline Industry FE & & Yes & Yes \\
\hline Year FE & & Yes & Yes \\
\hline
\end{tabular}


Table 6.3 (continued)

\begin{tabular}{|c|c|c|c|c|c|}
\hline & \multirow[b]{2}{*}{ Pred. } & \multicolumn{2}{|c|}{ H3B - EPS \$0.03 } & \multicolumn{2}{|c|}{ H3C - EPS \$0.03 } \\
\hline & & $\begin{array}{l}\mathrm{CEO}_{-} \\
\mathrm{DECP}\end{array}$ & $\begin{array}{c}\mathrm{CEO}_{-} \\
\mathrm{DECP}_{-} \mathrm{X}\end{array}$ & $\begin{array}{l}\mathrm{CEO}_{-} \\
\mathrm{DECP}^{-}\end{array}$ & $\begin{array}{c}\mathrm{CEO}_{-} \\
\mathrm{DECP}_{-} \mathrm{X}\end{array}$ \\
\hline \multirow[t]{2}{*}{ Constant } & & 0.07 & -0.217 & 0.115 & $-0.175^{* *}$ \\
\hline & & $(0.188)$ & $(-0.574)$ & $(1.595)$ & $(-2.433)$ \\
\hline \multirow[t]{2}{*}{ ABN_DISEXP } & + & $0.268^{*}$ & 0.168 & $0.326 * * *$ & $0.251 * * *$ \\
\hline & & $(1.971)$ & $(1.224)$ & $(8.395)$ & $(6.485)$ \\
\hline \multirow[t]{2}{*}{ LEV } & + & $-0.497 * *$ & $-0.436^{*}$ & 0.002 & -0.012 \\
\hline & & $(-2.134)$ & $(-1.853)$ & $(0.047)$ & $(-0.285)$ \\
\hline \multirow[t]{2}{*}{ ROA } & $?$ & 0.475 & 0.219 & $0.108^{*}$ & 0.023 \\
\hline & & $(1.45)$ & $(0.662)$ & (1.866) & $(0.396)$ \\
\hline \multirow[t]{2}{*}{ ASSETGROWTH } & $?$ & -0.085 & -0.037 & 0.002 & 0.007 \\
\hline & & $(-0.69)$ & $(-0.294)$ & $(0.129)$ & $(0.435)$ \\
\hline \multirow[t]{2}{*}{ lnASSETS } & $?$ & -0.014 & 0.028 & $0.014 * *$ & $0.058 * * *$ \\
\hline & & $(-0.4)$ & $(0.812)$ & $(2.031)$ & $(8.469)$ \\
\hline \multirow[t]{2}{*}{ RESTATE } & + & 0.122 & -0.2 & $-0.395^{* *}$ & $-0.331 * *$ \\
\hline & & $(0.247)$ & $(-0.4)$ & $(-2.432)$ & $(-2.044)$ \\
\hline \multirow[t]{2}{*}{ LOSS } & + & $0.389 * *$ & 0.207 & $-0.072 * *$ & $-0.126 * * *$ \\
\hline & & $(2.471)$ & (1.299) & $(-2.46)$ & $(-4.298)$ \\
\hline $\mathrm{n}$ & & 305 & 305 & 8276 & 8276 \\
\hline $\mathrm{R}^{2}$ & & 0.098 & 0.082 & 0.037 & 0.042 \\
\hline Industry FE & & Yes & Yes & Yes & Yes \\
\hline Year FE & & Yes & Yes & Yes & Yes \\
\hline
\end{tabular}


Table 6.3 (continued)

\begin{tabular}{|c|c|c|c|c|c|}
\hline & \multirow[b]{2}{*}{ Pred. } & \multicolumn{2}{|c|}{ H3B - Suspect } & \multicolumn{2}{|c|}{ H3C - Suspect } \\
\hline & & $\begin{array}{l}\mathrm{CEO}_{-} \\
\mathrm{DECP}^{-}\end{array}$ & $\begin{array}{c}\mathrm{CEO}_{-} \\
\mathrm{DECP}_{-} \mathrm{X}\end{array}$ & $\begin{array}{l}\mathrm{CEO}_{-} \\
\mathrm{DECP}^{-}\end{array}$ & $\begin{array}{c}\mathrm{CEO}_{-} \\
\mathrm{DECP} \mathrm{X}\end{array}$ \\
\hline Constant & & $\begin{array}{l}-0.244 \\
(-0.459)\end{array}$ & $\begin{array}{l}-0.264 \\
(-0.474)\end{array}$ & $\begin{array}{l}0.128 * \\
(1.792)\end{array}$ & $\begin{array}{l}-0.171^{*} \\
-2.407\end{array}$ \\
\hline ABN_DISEXP & + & $\begin{array}{l}0.762 * * \\
(2.051)\end{array}$ & $\begin{array}{l}0.466 \\
(1.19)\end{array}$ & $\begin{array}{l}0.302 * * * \\
(8.103)\end{array}$ & $\begin{array}{l}0.228^{* * * *} \\
6.14\end{array}$ \\
\hline LEV & + & $\begin{array}{l}0.506 \\
(1.23)\end{array}$ & $\begin{array}{l}0.542 \\
(1.253)\end{array}$ & $\begin{array}{l}-0.015 \\
(-0.369)\end{array}$ & $\begin{array}{l}-0.027 \\
-0.653\end{array}$ \\
\hline ROA & $?$ & $\begin{array}{l}2.547 \\
(1.27)\end{array}$ & $\begin{array}{l}1.617 \\
(0.766)\end{array}$ & $\begin{array}{l}0.105 * \\
(1.827)\end{array}$ & $\begin{array}{l}0.015 \\
0.257\end{array}$ \\
\hline ASSETGROWTH & $?$ & $\begin{array}{l}-0.043 * \\
(-1.864)\end{array}$ & $\begin{array}{l}-0.024 \\
(-0.986)\end{array}$ & $\begin{array}{l}0.021 \\
(0.921)\end{array}$ & $\begin{array}{l}0.027 \\
1.175\end{array}$ \\
\hline $\operatorname{lnASSETS}$ & $?$ & $\begin{array}{l}0.051 \\
(0.933)\end{array}$ & $\begin{array}{l}0.089 \\
(1.547)\end{array}$ & $\begin{array}{l}0.011 * \\
(1.676)\end{array}$ & $\begin{array}{l}0.056^{* * * *} \\
8.312\end{array}$ \\
\hline RESTATE & + & $\begin{array}{l}0.392 \\
(0.386)\end{array}$ & $\begin{array}{l}-0.601 \\
(-0.562)\end{array}$ & $\begin{array}{l}-0.377 * * \\
(-2.412)\end{array}$ & $\begin{array}{l}-0.335^{* *} \\
-2.152\end{array}$ \\
\hline LOSS & + & $\begin{array}{l}0.15 \\
(0.37)\end{array}$ & $\begin{array}{l}0.05 \\
(0.118)\end{array}$ & $\begin{array}{l}-0.063 * * \\
(-2.151)\end{array}$ & $\begin{array}{l}-0.121 * * * \\
-4.163\end{array}$ \\
\hline $\mathrm{n}$ & & 151 & 151 & 8430 & 8430 \\
\hline $\mathrm{R}^{2}$ & & 0.132 & 0.13 & 0.037 & 0.041 \\
\hline Industry FE & & Yes & Yes & Yes & Yes \\
\hline Year FE & & Yes & Yes & Yes & Yes \\
\hline
\end{tabular}




\section{Table 7.1}

This table depicts the results of hypothesis $4 a, 4 b$, and 4c, which tests the relationship between CFO deception and abnormal cashflows (ABN_CFO). The dependent variables used were the CFO deception measures, CFO_DECP and CFO_DECP_X. H4A tests the full sample population. H4B and C split the sample and respectively test the target and non-target firms. Target firms were defined in two ways, the first was if a firm had earnings per share within $\$ 0.03$ of last year's earnings per share. The suspect measure followed Roychowdhury (2006) and target firms were defined as those firms where net income scaled by assets is greater than or equal to zero but less than 0.005 . The coefficients are on the first line, and the t-statistics are in the parentheses $* * * \mathrm{p}<0.01, * * \mathrm{p}<0.05, * \mathrm{p}<0.1$

\section{H4A - All Firms}

\begin{tabular}{|c|c|c|c|}
\hline & Pred. & CFO_DECP & CFO_DECP_X \\
\hline \multirow[t]{2}{*}{ Constant } & & $-0.683 * * *$ & $-0.762 * * *$ \\
\hline & & $(-9.646)$ & $(-10.941)$ \\
\hline \multirow[t]{2}{*}{ ABN_CFO } & + & 0.169 & $0.235^{* *}$ \\
\hline & & (1.900) & $(2.691)$ \\
\hline \multirow[t]{2}{*}{ LEV } & + & 0.046 & $0.125^{* *}$ \\
\hline & & (1.094) & $(3.031)$ \\
\hline \multirow[t]{2}{*}{ ROA } & $?$ & -0.023 & -0.006 \\
\hline & & $(-0.372)$ & $(-1.825)$ \\
\hline \multirow[t]{2}{*}{ ASSETGROWTH } & $?$ & -0.011 & $-0.028 *$ \\
\hline & & $(-0.720)$ & $(-1.825)$ \\
\hline \multirow[t]{2}{*}{$\operatorname{lnASSETS}$} & $?$ & $0.094 * * *$ & $0.107 * * *$ \\
\hline & & (14.095) & (16.239) \\
\hline \multirow[t]{2}{*}{ RESTATE } & + & -0.169 & 0.034 \\
\hline & & $(-1.110)$ & $(0.226)$ \\
\hline \multirow[t]{2}{*}{ LOSS } & + & 0.028 & -0.019 \\
\hline & & $(0.972)$ & $(-0.645)$ \\
\hline $\mathrm{n}$ & & 8442 & 8442 \\
\hline $\mathrm{R}^{2}$ & & 0.041 & 0.073 \\
\hline Industry FE & & Yes & Yes \\
\hline Year FE & & Yes & Yes \\
\hline
\end{tabular}


Table 7.1 (continued)

\begin{tabular}{|c|c|c|c|c|c|}
\hline & \multirow[b]{2}{*}{ Pred. } & \multicolumn{2}{|c|}{ H4B - EPS \$0.03 } & \multicolumn{2}{|c|}{ H4C - EPS \$0.03 } \\
\hline & & $\begin{array}{l}\mathrm{CFO}_{-} \\
\mathrm{DECP}^{-}\end{array}$ & $\begin{array}{c}\mathrm{CFO}_{-} \\
\mathrm{DECP}_{-} \mathrm{X}\end{array}$ & $\begin{array}{l}\mathrm{CFO}_{-} \\
\mathrm{DECP}^{-}\end{array}$ & $\begin{array}{c}\mathrm{CFO}_{-} \\
\mathrm{DECP}_{-} \mathrm{X}\end{array}$ \\
\hline \multirow[t]{2}{*}{ Constant } & & -0.295 & -0.262 & $-0.706 * * *$ & $-0.792 * * *$ \\
\hline & & $(-0.795)$ & $(-0.676)$ & $(-9.751)$ & $(-11.154)$ \\
\hline \multirow[t]{2}{*}{ ABN_CFO } & + & -0.152 & -0.068 & $0.181 *$ & $0.223 * *$ \\
\hline & & $(-0.437)$ & $(-0.186)$ & (1.928) & $(2.414)$ \\
\hline \multirow[t]{2}{*}{ LEV } & + & -0.036 & 0.267 & 0.051 & $0.123 * *$ \\
\hline & & $(-0.146)$ & (1.047) & $(1.185)$ & $(2.939)$ \\
\hline \multirow[t]{2}{*}{ ROA } & $?$ & -0.091 & -0.287 & -0.022 & 0.003 \\
\hline & & $(-0.248)$ & $(-0.744)$ & $(-0.343)$ & $(0.042)$ \\
\hline \multirow[t]{2}{*}{ ASSETGROWTH } & $?$ & -0.111 & $-0.233^{*}$ & -0.010 & -0.024 \\
\hline & & $(-0.890)$ & $(-1.784)$ & $(-0.661)$ & $(-1.589)$ \\
\hline \multirow[t]{2}{*}{ lnASSETS } & $?$ & $0.067 *$ & $0.098 * *$ & $0.096 * * *$ & $0.109 * * *$ \\
\hline & & (1.928) & $(2.684)$ & (14.048) & (16.208) \\
\hline \multirow[t]{2}{*}{ RESTATE } & + & 0.224 & 0.525 & -0.196 & -0.003 \\
\hline & & $(0.396)$ & $(0.889)$ & (1.124) & $(-0.023)$ \\
\hline \multirow[t]{2}{*}{ LOSS } & + & -0.080 & -0.211 & 0.033 & -0.012 \\
\hline & & $(-0.502)$ & $(-1.271)$ & $(-0.186)$ & $(-0.400)$ \\
\hline $\mathrm{n}$ & & 292 & 292 & 8150 & 8150 \\
\hline $\mathrm{R}^{2}$ & & 0.063 & 0.130 & 0.042 & 0.073 \\
\hline Industry FE & & Yes & Yes & Yes & Yes \\
\hline Year FE & & Yes & Yes & Yes & Yes \\
\hline
\end{tabular}


Table 7.1 (continued)

\begin{tabular}{|c|c|c|c|c|c|}
\hline & \multirow[b]{2}{*}{ Pred. } & \multicolumn{2}{|c|}{ H4B - Suspect } & \multicolumn{2}{|c|}{ H4C - Suspect } \\
\hline & & $\begin{array}{l}\mathrm{CFO}_{-} \\
\mathrm{DECP}\end{array}$ & ${ }_{\text {DECP_X }}^{\mathrm{CFO}_{-}}$ & $\begin{array}{l}\mathrm{CFO}_{-} \\
\mathrm{DECP}\end{array}$ & $\begin{array}{c}\mathrm{CFO}_{-} \\
\mathrm{DECP} \_\mathrm{X}\end{array}$ \\
\hline Constant & & $\begin{array}{l}-0.556 \\
(-1.004)\end{array}$ & $\begin{array}{l}-0.790 \\
(-1.335)\end{array}$ & $\begin{array}{l}-0.670 * * * \\
(-9.349)\end{array}$ & $\begin{array}{l}-0.740 * * * \\
(-10.509)\end{array}$ \\
\hline ABN_CFO & + & $\begin{array}{l}1.801 \\
(1.595)\end{array}$ & $\begin{array}{l}2.309 * \\
(1.915)\end{array}$ & $\begin{array}{l}0.140 \\
(1.563)\end{array}$ & $\begin{array}{l}0.200 * * \\
(2.274)\end{array}$ \\
\hline LEV & + & $\begin{array}{l}-0.669 \\
(-1.533)\end{array}$ & $\begin{array}{l}-0.179 \\
(-0.384)\end{array}$ & $\begin{array}{l}0.051 \\
(1.209)\end{array}$ & $\begin{array}{l}0.125 * * \\
(3.014)\end{array}$ \\
\hline ROA & $?$ & $\begin{array}{l}-3.331 \\
(-1.561)\end{array}$ & $\begin{array}{l}-3.043 \\
(-1.336)\end{array}$ & $\begin{array}{l}0.001 \\
(0.010)\end{array}$ & $\begin{array}{l}0.016 \\
(0.264)\end{array}$ \\
\hline ASSETGROWTH & $?$ & $\begin{array}{l}0.016 \\
(0.662)\end{array}$ & $\begin{array}{l}-0.001 \\
(-0.057)\end{array}$ & $\begin{array}{l}-0.055^{* *} \\
(-2.351)\end{array}$ & $\begin{array}{l}-0.076^{* *} \\
(-3.279)\end{array}$ \\
\hline lnASSETS & $?$ & $\begin{array}{l}0.110 * \\
(1.834)\end{array}$ & $\begin{array}{l}0.109 * \\
(1.701)\end{array}$ & $\begin{array}{l}0.094 * * * \\
(13.865)\end{array}$ & $\begin{array}{l}0.106 * * * \\
(15.976)\end{array}$ \\
\hline RESTATE & + & $\begin{array}{l}1.343 \\
(1.248)\end{array}$ & $\begin{array}{l}-0.095 \\
(-0.082)\end{array}$ & $\begin{array}{l}-0.201 \\
(-1.312)\end{array}$ & $\begin{array}{l}0.035 \\
(0.231)\end{array}$ \\
\hline LOSS & + & $\begin{array}{l}-0.773 * \\
(-1.795)\end{array}$ & $\begin{array}{l}-0.502 \\
(1.529)\end{array}$ & $\begin{array}{l}0.033 \\
(1.109)\end{array}$ & $\begin{array}{l}-0.017 \\
(-0.605)\end{array}$ \\
\hline $\mathrm{n}$ & & 146 & 146 & 8296 & 8296 \\
\hline $\mathrm{R}^{2}$ & & 0.177 & 0.158 & 0.042 & 0.074 \\
\hline Industry FE & & Yes & Yes & Yes & Yes \\
\hline Year FE & & Yes & Yes & Yes & Yes \\
\hline
\end{tabular}




\section{Table 7.2}

This table depicts the results of hypothesis $4 \mathrm{a}, 4 \mathrm{~b}$, and 4c, which tests the relationship between CFO deception and abnormal production costs (ABN_PROD). The dependent variables used were the CFO deception measures, CFO_DECP and CFO_DECP_X. H4A tests the full sample population. H4B and C split the sample and respectively test the target and non-target firms. Target firms were defined in two ways, the first was if a firm had earnings per share within $\$ 0.03$ of last year's earnings per share. The suspect measure followed Roychowdhury (2006) and target firms were defined as those firms where net income scaled by assets is greater than or equal to zero but less than 0.005 . The coefficients are on the first line, and the t-statistics are in the parentheses $* * * \mathrm{p}<0.01, * * \mathrm{p}<0.05, * \mathrm{p}<0.1$

\section{H4A - All Firms}

\begin{tabular}{|c|c|c|c|}
\hline & Pred. & CFO_DECP & CFO_DECP_X \\
\hline \multirow[t]{2}{*}{ Constant } & & $-0.683 * * *$ & $-0.765 * * *$ \\
\hline & & $(-9.640)$ & $(-10.988)$ \\
\hline \multirow[t]{2}{*}{ ABN_PROD } & + & -0.096 & $-0.183 * *$ \\
\hline & & $(-1.584)$ & $(-3.084)$ \\
\hline \multirow{2}{*}{ LEV } & + & 0.043 & $0.122 * *$ \\
\hline & & (1.029) & $(2.947)$ \\
\hline \multirow[t]{2}{*}{ ROA } & $?$ & 0.005 & 0.028 \\
\hline & & $(0.085)$ & $(0.478)$ \\
\hline \multirow[t]{2}{*}{ ASSETGROWTH } & $?$ & -0.014 & $-0.031 * *$ \\
\hline & & $(-0.878)$ & $(-2.065)$ \\
\hline \multirow[t]{2}{*}{ lnASSETS } & $?$ & $0.095 * * *$ & $0.108 * * *$ \\
\hline & & (14.088) & (16.318) \\
\hline \multirow[t]{2}{*}{ RESTATE } & + & -0.158 & 0.055 \\
\hline & & $(-1.039)$ & $(0.370)$ \\
\hline \multirow[t]{2}{*}{ LOSS } & + & 0.023 & -0.025 \\
\hline & & $(0.799)$ & $(-0.884)$ \\
\hline $\mathrm{n}$ & & 8442 & 8442 \\
\hline $\mathrm{R}^{2}$ & & 0.041 & 0.073 \\
\hline Industry FE & & Yes & Yes \\
\hline Year FE & & Yes & Yes \\
\hline
\end{tabular}


Table 7.2 (continued)

\begin{tabular}{|c|c|c|c|c|c|}
\hline & \multirow[b]{2}{*}{ Pred. } & \multicolumn{2}{|c|}{ H4B - EPS \$0.03 } & \multicolumn{2}{|c|}{ H4C - EPS \$0.03 } \\
\hline & & $\begin{array}{l}\mathrm{CFO}_{-} \\
\mathrm{DECP}^{-}\end{array}$ & $\begin{array}{c}\mathrm{CFO}_{-} \\
\mathrm{DECP}_{-} \mathrm{X}\end{array}$ & $\begin{array}{l}\mathrm{CFO}_{-} \\
\mathrm{DECP}\end{array}$ & $\begin{array}{c}\mathrm{CFO}_{-} \\
\mathrm{DECP} \_\mathrm{X}\end{array}$ \\
\hline Constant & & $\begin{array}{l}-0.341 \\
(-0.922)\end{array}$ & $\begin{array}{l}-0.300 \\
(-0.777)\end{array}$ & $\begin{array}{l}-0.705 * * * \\
(-9.735)\end{array}$ & $\begin{array}{l}-0.796 * * * \\
(-11.207)\end{array}$ \\
\hline ABN_PROD & + & $\begin{array}{l}-0.283 \\
(-1.015)\end{array}$ & $\begin{array}{l}-0.307 \\
(-1.055)\end{array}$ & $\begin{array}{l}-0.084 \\
(-1.354)\end{array}$ & $\begin{array}{l}-0.172 * * \\
(-2.837)\end{array}$ \\
\hline LEV & + & $\begin{array}{l}-0.032 \\
(-0.131)\end{array}$ & $\begin{array}{l}0.275 \\
(1.078)\end{array}$ & $\begin{array}{l}0.047 \\
(1.097)\end{array}$ & $\begin{array}{l}0.119 * * \\
(2.839)\end{array}$ \\
\hline ROA & $?$ & $\begin{array}{l}-0.142 \\
(-0.411)\end{array}$ & $\begin{array}{l}-0.307 \\
(-0.848)\end{array}$ & $\begin{array}{l}0.009 \\
(0.147)\end{array}$ & $\begin{array}{l}0.033 \\
(0.558)\end{array}$ \\
\hline ASSETGROWTH & $?$ & $\begin{array}{l}-0.080 \\
(-0.811)\end{array}$ & $\begin{array}{l}-0.220 * * \\
(-2.137)\end{array}$ & $\begin{array}{l}-0.012 \\
(-0.759)\end{array}$ & $\begin{array}{l}-0.027^{*} \\
(-1.733)\end{array}$ \\
\hline lnASSETS & $?$ & $\begin{array}{l}0.071 * * \\
(2.075)\end{array}$ & $\begin{array}{l}0.100 * * \\
(2.799)\end{array}$ & $\begin{array}{l}0.096 * * * \\
(14.026)\end{array}$ & $\begin{array}{l}0.110 * * * \\
(16.295)\end{array}$ \\
\hline RESTATE & + & $\begin{array}{l}0.251 \\
(0.445)\end{array}$ & $\begin{array}{l}0.550 \\
(0.933)\end{array}$ & $\begin{array}{l}-0.187 \\
(-1.180)\end{array}$ & $\begin{array}{l}0.018 \\
(0.119)\end{array}$ \\
\hline LOSS & + & $\begin{array}{l}-0.062 \\
(-0.391)\end{array}$ & $\begin{array}{l}-0.195 \\
(-1.176)\end{array}$ & $\begin{array}{l}0.028 \\
(0.935)\end{array}$ & $\begin{array}{l}-0.018 \\
(-0.624)\end{array}$ \\
\hline $\mathrm{n}$ & & 292 & 292 & 8150 & 8150 \\
\hline $\mathrm{R}^{2}$ & & 0.066 & 0.134 & 0.042 & 0.074 \\
\hline Industry FE & & Yes & Yes & Yes & Yes \\
\hline Year FE & & Yes & Yes & Yes & Yes \\
\hline
\end{tabular}


Table 7.2 (continued)

\begin{tabular}{|c|c|c|c|c|c|}
\hline & \multirow[b]{2}{*}{ Pred. } & \multicolumn{2}{|c|}{ H4B - Suspect } & \multicolumn{2}{|c|}{ H4C - Suspect } \\
\hline & & $\begin{array}{l}\mathrm{CFO}_{-} \\
\mathrm{DECP}^{-}\end{array}$ & $\begin{array}{c}\mathrm{CFO}_{-} \\
\mathrm{DECP}_{-} \mathrm{X}\end{array}$ & $\begin{array}{l}\mathrm{CFO}_{-} \\
\mathrm{DECP}^{-}\end{array}$ & $\begin{array}{c}\mathrm{CFO}_{-} \\
\mathrm{DECP}_{-} \mathrm{X}\end{array}$ \\
\hline \multirow[t]{2}{*}{ Constant } & & -0.800 & $-1.117 *$ & $-0.669 * * *$ & $-0.742 * * *$ \\
\hline & & $(-1.444)$ & $(-1.892)$ & $(-9.338)$ & $(-10.540)$ \\
\hline \multirow[t]{2}{*}{ ABN_PROD } & + & -0.679 & $-0.948 * *$ & -0.085 & $-0.167 * *$ \\
\hline & & $(-1.594)$ & $(-2.091)$ & $(-1.396)$ & $(-2.775)$ \\
\hline \multirow[t]{2}{*}{ LEV } & + & $-0.730^{*}$ & -0.254 & 0.049 & $0.122 * *$ \\
\hline & & $(-1.685)$ & $(-0.550)$ & (1.152) & $(2.938)$ \\
\hline \multirow[t]{2}{*}{ ROA } & $?$ & -3.085 & -2.724 & 0.024 & 0.045 \\
\hline & & $(-1.449)$ & $(-1.201)$ & $(0.403)$ & $(0.774)$ \\
\hline \multirow[t]{2}{*}{ ASSETGROWTH } & $?$ & 0.015 & -0.002 & $-0.060 * *$ & $-0.083 * * *$ \\
\hline & & $(0.643)$ & $(-0.087)$ & $(-2.568)$ & $(-3.615)$ \\
\hline \multirow[t]{2}{*}{ lnASSETS } & $?$ & $0.134 * *$ & $0.142 * *$ & $0.094 * * *$ & $0.107 * * *$ \\
\hline & & $(2.217)$ & $(2.201)$ & (13.859) & (16.046) \\
\hline \multirow[t]{2}{*}{ RESTATE } & + & 1.284 & -0.176 & -0.192 & 0.055 \\
\hline & & (1.193) & $(-0.153)$ & $(-1.246)$ & $(0.366)$ \\
\hline \multirow[t]{2}{*}{ LOSS } & + & $-0.726^{*}$ & -0.442 & 0.028 & -0.023 \\
\hline & & $(-1.691)$ & $(-0.968)$ & $(0.968)$ & $(-0.806)$ \\
\hline $\mathrm{n}$ & & 146 & 146 & 8296 & 8296 \\
\hline $\mathrm{R}^{2}$ & & 0.177 & 0.163 & 0.042 & .074 \\
\hline Industry FE & & Yes & Yes & Yes & Yes \\
\hline Year FE & & Yes & Yes & Yes & Yes \\
\hline
\end{tabular}


Table 7.3

This table depicts the results of hypothesis $4 a, 4 b$, and $4 c$, which tests the relationship between CFO deception and abnormal discretionary expenses (ABN_DISEXP). The dependent variables used were the CFO deception measures, CFO_DECP and CFO_DECP_X. H4A tests the full sample population. H4B and C split the sample and respectively test the target and non-target firms. Target firms were defined in two ways, the first was if a firm had earnings per share within $\$ 0.03$ of last year's earnings per share. The suspect measure followed Roychowdhury (2006) and target firms were defined as those firms where net income scaled by assets is greater than or equal to zero but less than 0.005 . The coefficients are on the first line, and the t-statistics are in the parentheses $* * * \mathrm{p}<0.01, * * \mathrm{p}<0.05, * \mathrm{p}<0.1$

\section{H4A - All Firms}

\begin{tabular}{|c|c|c|c|}
\hline & Pred. & CFO_DECP & CFO_DECP_X \\
\hline \multirow[t]{2}{*}{ Constant } & & $-0.678 * * *$ & $-0.753 * * *$ \\
\hline & & $(-9.591)$ & $(-10.828)$ \\
\hline \multirow[t]{2}{*}{ ABN_DISEXP } & + & 0.043 & 0.024 \\
\hline & & $(1.165)$ & $(0.651)$ \\
\hline \multirow[t]{2}{*}{ LEV } & + & 0.044 & $0.121 * *$ \\
\hline & & $(1.050)$ & $(2.938)$ \\
\hline \multirow[t]{2}{*}{ ROA } & $?$ & 0.025 & 0.052 \\
\hline & & $(0.426)$ & $(0.887)$ \\
\hline \multirow[t]{2}{*}{ ASSETGROWTH } & $?$ & -0.016 & $-0.032 * *$ \\
\hline & & $(-1.028)$ & $(-2.089)$ \\
\hline \multirow[t]{2}{*}{ lnASSETS } & $?$ & $0.094 * * *$ & $0.106 * * *$ \\
\hline & & $(14.035)$ & (16.108) \\
\hline \multirow[t]{2}{*}{ RESTATE } & + & -0.167 & 0.032 \\
\hline & & $(-1.097)$ & $(0.215)$ \\
\hline \multirow[t]{2}{*}{ LOSS } & + & 0.020 & -0.029 \\
\hline & & $(0.679)$ & $(-0.998)$ \\
\hline $\mathrm{n}$ & & 8442 & 8442 \\
\hline $\mathrm{R}^{2}$ & & 0.041 & 0.072 \\
\hline Industry FE & & Yes & Yes \\
\hline Year FE & & Yes & Yes \\
\hline
\end{tabular}


Table 7.3 (continued)

\begin{tabular}{|c|c|c|c|c|c|}
\hline & \multirow[b]{2}{*}{ Pred } & \multicolumn{2}{|c|}{ H4B - EPS \$0.03 } & \multicolumn{2}{|c|}{ H4C - EPS \$0.03 } \\
\hline & & $\underset{\mathrm{P}}{\text { CFO_DEC }}$ & $\underset{\mathrm{X}}{\mathrm{CFO}+\mathrm{DECP}}$ & $\underset{\mathrm{P}}{\text { CFO_DEC }}$ & $\underset{\mathrm{X}}{\mathrm{CFO}{ }^{\mathrm{DECP}}}$ \\
\hline \multirow[t]{2}{*}{ Constant } & & -0.308 & -0.272 & $-0.703 * * *$ & $-0.787 * * *$ \\
\hline & & $(-0.834)$ & $(-0.705)$ & $(-9.707)$ & $(-11.087)$ \\
\hline \multirow[t]{2}{*}{ ABN_DISEXP } & + & 0.098 & -0.032 & 0.046 & 0.046 \\
\hline & & $(0.706)$ & $(-0.222)$ & (1.170) & (1.172) \\
\hline \multirow[t]{2}{*}{ LEV } & + & -0.017 & 0.257 & 0.048 & $0.119 * *$ \\
\hline & & $(-0.067)$ & $(1.000)$ & (1.113) & $(2.843)$ \\
\hline \multirow[t]{2}{*}{ ROA } & $?$ & -0.091 & -0.329 & 0.028 & 0.061 \\
\hline & & $(-0.255)$ & $(-0.887)$ & $(0.465)$ & $(1.030)$ \\
\hline \multirow{3}{*}{$\begin{array}{l}\text { ASSETGROWT } \\
\mathrm{H}\end{array}$} & & & & & \\
\hline & $?$ & -0.133 & -0.200 & -0.014 & $-0.028 *$ \\
\hline & & $(-1.055)$ & $(-1.513)$ & $(-0.892)$ & $(-1.830)$ \\
\hline \multirow[t]{2}{*}{ lnASSETS } & $?$ & $0.067 *$ & $0.100 * *$ & $0.096 * * *$ & $0.108 * * *$ \\
\hline & & (1.947) & $(2.776)$ & $(14.001)$ & (16.132) \\
\hline \multirow[t]{2}{*}{ RESTATE } & + & 0.227 & 0.530 & -0.193 & -0.001 \\
\hline & & $(0.401)$ & $(0.898)$ & $(-1.223)$ & $(-0.009)$ \\
\hline \multirow[t]{2}{*}{ LOSS } & + & -0.082 & -0.206 & 0.024 & -0.022 \\
\hline & & $(-0.516)$ & $(-1.245)$ & $(0.822)$ & $(-0.764)$ \\
\hline $\mathrm{n}$ & & 292 & 292 & 8150 & 8150 \\
\hline $\mathrm{R}^{2}$ & & 0.064 & 0.130 & 0.042 & 0.073 \\
\hline Industry FE & & Yes & Yes & Yes & Yes \\
\hline Year FE & & Yes & Yes & Yes & Yes \\
\hline
\end{tabular}


Table 7.3 (continued)

\begin{tabular}{|c|c|c|c|c|c|}
\hline & \multirow[b]{2}{*}{ Pred } & \multicolumn{2}{|c|}{ H4B - Suspect } & \multicolumn{2}{|c|}{ H4C - Suspect } \\
\hline & & $\underset{\mathrm{P}}{\text { CFO_DEC }}$ & $\begin{array}{c}\mathrm{CFO}_{\mathrm{X}} \mathrm{DECP} \\
-\end{array}$ & $\underset{\mathrm{P}}{\mathrm{CFO} D \mathrm{DEC}}$ & $\begin{array}{c}\mathrm{CFO}_{\mathrm{X}} \mathrm{DECP} \\
-\end{array}$ \\
\hline Constant & & $\begin{array}{l}-0.746 \\
(-1.325)\end{array}$ & $\begin{array}{l}-1.053 * \\
(-1.750)\end{array}$ & $\begin{array}{l}-0.665 * * * \\
(-9.298)\end{array}$ & $\begin{array}{l}-0.732 * * * \\
(-10.405)\end{array}$ \\
\hline ABN_DISEXP & + & $\begin{array}{l}0.272 \\
(0.676)\end{array}$ & $\begin{array}{l}0.432 \\
(1.002)\end{array}$ & $\begin{array}{l}0.058 \\
(1.533)\end{array}$ & $\begin{array}{l}0.037 \\
(1.002)\end{array}$ \\
\hline LEV & + & $\begin{array}{l}-0.734 * \\
(-1.676)\end{array}$ & $\begin{array}{l}-0.255 \\
(-0.544)\end{array}$ & $\begin{array}{l}0.050 \\
(1.181)\end{array}$ & $\begin{array}{l}0.122 * * \\
(2.942)\end{array}$ \\
\hline ROA & $?$ & $\begin{array}{l}-3.117 \\
(-1.451)\end{array}$ & $\begin{array}{l}-2.767 \\
(-1.204)\end{array}$ & $\begin{array}{l}0.047 \\
(0.795)\end{array}$ & $\begin{array}{l}0.071 \\
(1.210)\end{array}$ \\
\hline $\begin{array}{l}\text { ASSETGROWT } \\
\mathrm{H}\end{array}$ & $?$ & $\begin{array}{l}0.014 \\
(0.564)\end{array}$ & $\begin{array}{l}-0.005 \\
(-0.190)\end{array}$ & $\begin{array}{l}-0.068 * * \\
(-2.816)\end{array}$ & $\begin{array}{l}-0.087 * * * \\
(-3.674)\end{array}$ \\
\hline lnASSETS & $?$ & $\begin{array}{l}0.124 * * \\
(2.041)\end{array}$ & $\begin{array}{l}0.128 * \\
(1.979)\end{array}$ & $\begin{array}{l}0.093 * * * \\
(13.833)\end{array}$ & $\begin{array}{l}0.105 * * * \\
(15.877)\end{array}$ \\
\hline RESTATE & + & $\begin{array}{l}1.293 \\
(1.190)\end{array}$ & $\begin{array}{l}-0.170 \\
(-0.146)\end{array}$ & $\begin{array}{l}-0.197 \\
(-1.285)\end{array}$ & $\begin{array}{l}0.035 \\
(0.234)\end{array}$ \\
\hline LOSS & + & $\begin{array}{l}-0.700 \\
(-1.611)\end{array}$ & $\begin{array}{l}-0.402 \\
(-0.864)\end{array}$ & $\begin{array}{l}0.024 \\
(0.820)\end{array}$ & $\begin{array}{l}-0.027 \\
(-0.946)\end{array}$ \\
\hline $\mathrm{n}$ & & 146 & 146 & 8296 & 8296 \\
\hline $\mathrm{R}^{2}$ & & 0.163 & 0.140 & 0.042 & 0.073 \\
\hline Industry FE & & Yes & Yes & Yes & Yes \\
\hline Year FE & & Yes & Yes & Yes & Yes \\
\hline
\end{tabular}

